\title{
Differences Between the Negatively Activating Potassium Conductances of Mammalian Cochlear and Vestibular Hair Cells
}

\author{
Weng Hoe Wong, ${ }^{1,2}$ Karen M. Hurley, ${ }^{1}$ and Ruth Anne Eatock ${ }^{1}$ \\ ${ }^{1}$ The Bobby R. Alford Department of Otorhinolaryngology and Communicative Sciences, Baylor College of Medicine, \\ One Baylor Plaza, Houston, TX 77030, USA \\ ${ }^{2}$ Department of Sensory Medicine, Division of Otorhinolaryngology, Head and Neck Surgery, \\ Akita University School of Medicine, 1-1-1 Hondo, Akita City, Akita Prefecture, 010-8543 Japan
}

Received: 8 December 2003; Accepted: 25 March 2004; Online publication: 30 July 2004

\begin{abstract}
Cochlear and type I vestibular hair cells of mammals express negatively activating potassium $\left(\mathrm{K}^{+}\right)$conductances, called $g_{\mathrm{K}, \mathrm{n}}$ and $g_{\mathrm{K}, \mathrm{L}}$ respectively, which are important in setting the hair cells' resting potentials and input conductances. It has been suggested that the channels underlying both conductances include KCNQ4 subunits from the KCNQ family of $\mathrm{K}^{+}$channels. In whole-cell recordings from rat hair cells, we found substantial differences between $g_{\mathrm{K}, \mathrm{n}}$ and $g_{\mathrm{K}, \mathrm{L}}$ in voltage dependence, kinetics, ionic permeability, and stability during whole-cell recording. Relative to $g_{\mathrm{K}, \mathrm{L}}$, $g_{\mathrm{K}, \mathrm{n}}$ had a significantly broader and more negative voltage range of activation and activated with less delay and faster principal time constants over the negative part of the activation range. Deactivation of $g_{\mathrm{K}, \mathrm{n}}$ had an unusual sigmoidal time course, while $g_{\mathrm{K}, \mathrm{L}}$ deactivated with a double-exponential decay. $g_{\mathrm{K}, \mathrm{L}}$, but not $g_{\mathrm{K}, \mathrm{n}}$, had appreciable permeability to $\mathrm{Cs}^{+}$. Unlike $g_{\mathrm{K}, \mathrm{L}}, g_{\mathrm{K}, \mathrm{n}}$ 's properties did not change ("wash out") during the replacement of cytoplasmic solution with pipette solution during ruptured-patch recordings. These differences in the functional expression of $g_{\mathrm{K}, \mathrm{n}}$ and $g_{\mathrm{K}, \mathrm{L}}$ channels suggest that there are substantial differences in their molecular structure as well.
\end{abstract}

Correspondence to: Ruth Anne Eatock - Department of Otolaryngology $\cdot$ Baylor College of Medicine - One Baylor Plaza - Houston, TX 77030 - Telephone: (713) 798-5145 or 5144; fax: 713-7988552; email: eatock@bcm.tmc.edu
Keywords: potassium channels, hair cells, inner ear, cochlea, vestibular

\section{INTRODUCTION}

In hair cells from several well-studied inner ear epithelia from nonmammals, there are relatively few ion channels open at resting potential: $5 \%-20 \%$ of the 100 or so transduction channels at the resting bundle position (Hudspeth and Corey 1977; Fettiplace 1992), plus small percentages of voltage-gated and $\mathrm{Ca}^{2+}$-gated channels (Art and Fettiplace 1987; Hudspeth and Lewis 1988; Fuchs et al. 1988; Sugihara and Furukawa 1989; Smotherman and Narins 1999). As a consequence, the hair cells have large input resistances and generate receptor potentials that are tens of millivolts in response to modest transduction currents. Many mammalian hair cells, in contrast, have significant numbers of open voltage-gated $\mathrm{K}^{+}$channels at resting potential, with correspondingly low input resistances. These channels are deactivated by hyperpolarizing voltage steps and therefore do not belong to the families of inwardly rectifying or hyperpolarization-activated channels that dominate at resting potential in other hair cells.

In the cochlea, a negatively activating conductance, $g_{\mathrm{K}, \mathrm{n}}$, is found in outer hair cells of all turns and is largest in the basal turn (Housley and Ashmore 1992; Mammano and Ashmore 1996). Recently, $g_{\mathrm{K}, \mathrm{n}}$ has also been reported in inner hair cells of both 
apical and basal turns of the mouse cochlea (Oliver et al. 2003; Marcotti et al. 2003). $g_{\mathrm{K}, \mathrm{n}}$ is not found in neonatal cells but is acquired at about the same time as the onset of hearing in the second postnatal week (Marcotti and Kros 1999; Marcotti et al. 2003). Upon its acquisition, the input resistance of hair cells falls, proportionately reducing the voltage change per unit transduction current and the membrane time constant. Both effects may be significant in enhancing sound processing - the attenuation of the steady-state receptor potential may reduce nonlinearities and the smaller time constant will expand the receptor potential bandwidth. $g_{\mathrm{K}, \mathrm{n}}$ may also be an important part of an hypothetical $\mathrm{K}^{+}$recycling pathway within the cochlea. By this scheme, $\mathrm{K}^{+}$enters hair cells through mechanoelectrical transduction channels in the bundle, exits the hair cell via $g_{\mathrm{K}, \mathrm{n}}$ and other $\mathrm{K}^{+}$selective channels located at the synaptic pole of the hair cell (Santos-Sacchi et al. 1997), then travels through a system of gap junctions to the stria vascularis (reviewed in Santos-Sacchi 2000; Kikuchi et al. 2000; Wangemann 2002).

$g_{\mathrm{K}, \mathrm{n}}$ is blocked by low concentrations of linopirdine (Marcotti and Kros 1999), a selective blocker of members of the KCNQ family of voltage-gated $\mathrm{K}^{+}$ channels. Each KCNQ channel, like other $\mathrm{K}^{+}$channels, comprises four $\alpha$ subunits that together form a pore. There are five known KCNQ $\alpha$ subunits (KCNQ1-5). When expressed in heterologous systems such as oocytes or cell lines, KCNQ $\alpha$ subunits can form homomultimeric channels of four identical subunits. In addition, KCNQ3 can form heteromultimers in combination with KCNQ2 (Wang et al. 1998), KCNQ4 (Kubisch et al. 1999), and KCNQ5 (Schroeder et al. 2000). The M current of sympathetic and brain neurons is thought to flow through KCNQ2/3 and/or KCNQ3/5 heteromultimers (Wang et al. 1998; Schroeder et al. 2000; Shah et al. 2002). There may be additional ( $\beta$ ) subunits; KCNQ1 associates with KCNE1 ( $\operatorname{minK}$ ) and possibly KCNE5 subunits to form a cardiac delayed rectifier current, $I_{\mathrm{Ks}}$ (Sanguinetti et al. 1996; Angelo et al. 2002). Given that KCNQ4 subunits are expressed by both outer and inner hair cells of mouse and rat cochleas $(\mathrm{Ku}-$ bisch et al. 1999; Beisel et al. 2000; Kharkovets et al. 2000; Oliver et al. 2003) and that $g_{\mathrm{K}, \mathrm{n}}$ is the only known linopirdine-sensitive conductance in these cells (Marcotti and Kros 1999; Marcotti et al. 2003), it follows that $g_{\mathrm{K}, \mathrm{n}}$ includes KCNQ4 subunits.

Type I hair cells of the vestibular organs of mammals, birds, and reptiles also express a negatively activating voltage-gated conductance (Correia and Lang $1990)$, called $g_{\mathrm{KI}}$ for "type-I-specific" $\mathrm{K}^{+}$conductance (Rennie and Correia 1994) or $g_{\mathrm{K}, \mathrm{L}}$ for "low-voltageactivated" ' $\mathrm{K}^{+}$conductance (Eatock et al. 1994). $g_{\mathrm{K}, \mathrm{L}}$ is a very large conductance that confers an unusually low input resistance (10-50 M $\Omega$ ) (Rennie et al. 1996; Rüsch and Eatock 1996b; Chen and Eatock 2000). $g_{\mathrm{K}, \mathrm{L}}$ resembles $g_{\mathrm{K}, \mathrm{n}}$ in its negative voltage range of activation and in its relatively late appearance in hair cell development, during the first postnatal week in the mouse utricle (Rüsch et al. 1998) and slightly later in the rat utricle (Eatock and Hurley 2003). This timing is coincident with the appearance on type I cells of distinctive calyceal afferent endings (Rüsch et al. 1998). Kubisch et al. (1999) and Kharkovets et al. (2000) reported high KCNQ4 mRNA expression and immunoreactivity, respectively, in vestibular epithelia beginning in the first postnatal week, leading them to suggest that $g_{\mathrm{K}, \mathrm{L}}$ channels, like $g_{\mathrm{K}, \mathrm{n}}$ channels, include KCNQ4 subunits.

$g_{\mathrm{K}, \mathrm{L}}$ and $g_{\mathrm{K}, \mathrm{n}}$ have different sensitivities to K channel blockers, however. $g_{\mathrm{K}, \mathrm{L}}$ is relatively insensitive to linopirdine (Rennie et al. 2001), which potently blocks $g_{\mathrm{K}, \mathrm{n}}$ (Marcotti and Kros 1999). $g_{\mathrm{K}, \mathrm{L}}$ is sensitive to 4-aminopyridine (Griguer et al. 1993; Rennie and Correia 1994; Rüsch and Eatock 1996a; Brichta et al. 2002), but $g_{\mathrm{K}, \mathrm{n}}$ is not (Mammano et al. 1995; Oliver et al. 2003). Published records of voltage-evoked currents in type I and outer hair cells also suggest kinetic and other differences, but differences in experimental protocols make it difficult to draw firm conclusions. Knowing whether $g_{\mathrm{K}, \mathrm{n}}$ and $g_{\mathrm{K}, \mathrm{L}}$ are related at the biophysical and molecular levels is of value in thinking about the functions and evolution of negatively activating conductances in hair cells. Our goal in these experiments was to obtain data permitting direct comparisons of the biophysical properties of $g_{\mathrm{K}, \mathrm{n}}$ and $g_{\mathrm{K}, \mathrm{L}}$. We found marked differences in their voltage range of activation, kinetics, and permeability. Either the proposal that both $g_{\mathrm{K}, \mathrm{n}}$ and $g_{\mathrm{K}, \mathrm{L}}$ are KCNQ4 channels is wrong, or the subunits express themselves very differently in the two hair cell types, e.g., through associations with different subunit partners or such post-translational modifications as phosphorylation (see Discussion).

\section{METHODS}

Whole-cell currents were recorded from outer hair cells isolated from the apical turns of rat cochleas on postnatal days (P) 14-17, several days after hearing onset (Rübsamen and Lippe 1998). At this age, several measures of outer hair cell function have matured, including the cochlear microphonic potential (reflecting outer hair cell transduction) (Uziel et al. 1981) and the amplitude of electromotility (Beurg et al. 2001). The outer hair cell currents are compared with results from type I hair cells isolated from the sensory epithelium of the rat utricle on P16-P24. At this age, type I hair cells in mice and rats have acquired $g_{\mathrm{K}, \mathrm{L}}$ (Rüsch et al. 1998; Eatock and Hurley 2003). 


\section{Preparation of hair cells}

All procedures for handling animals were approved by the animal care review committee of Baylor College of Medicine. Long-Evans rats were deeply anesthetized with pentobarbital sodium (Nembutal, 50$100 \mathrm{mg} / \mathrm{kg} \mathrm{IP}$ ) and then decapitated.

Outer hair cell solutions. Salts, enzymes, and other compounds were obtained from Sigma (St. Louis, MO) unless otherwise stated. For dissections and cell dissociation, we supplemented Leibovitz's L-15 medium (Gibco BRL, Gaithersburg, MD) with $10 \mathrm{mM} \mathrm{N}$ 2-hydroxyethylpiperazine-N'-2-ethanesulfonic acid (HEPES) and then further modified its $\mathrm{Ca}^{2+}$ level in one of two ways. For the dissection and recordings, we added $2 \mathrm{mM} \mathrm{Ca}^{2+}$ ("high-Ca ${ }^{2+} \mathrm{L}-15$ "). High-Ca ${ }^{2+} \mathrm{L}-$ 15 contains (in mM) $139 \mathrm{Na}^{+}, 5.8 \mathrm{~K}^{+}, 3.3 \mathrm{Ca}^{2+}, 1.8$ $\mathrm{Mg}^{2+}, 147 \mathrm{Cl}^{-}, 0.8 \mathrm{SO}_{4}{ }^{2-}, 0.8 \mathrm{HPO}_{4}{ }^{2-}, 0.4 \mathrm{H}_{2} \mathrm{PO}_{4}{ }^{1-}$, plus amino acids and vitamins. For the enzymatic and mechanical dissociation steps, we added $1.2 \mathrm{mM}$ EGTA to reduce $\mathrm{Ca}^{2+}$ to $100 \mu \mathrm{M}$ ("low- $\mathrm{Ca}^{2+} \mathrm{L}-15$ "). Both solutions were adjusted to $\mathrm{pH} 7.3$ and had osmolalities of 315-325 mmol/ $\mathrm{kg}$.

Vestibular hair cell solutions. The external medium ("vestibular medium") used for all procedures (dissection, dissociation, and standard recording) contained (in mM) $144 \mathrm{Na}^{+}, 5.8 \mathrm{~K}^{+}, 1.3 \mathrm{Ca}^{2+}, 0.9 \mathrm{Mg}^{2+}$, $154.2 \mathrm{Cl}^{-}, 10 \mathrm{HEPES}$, and $5.6 \mathrm{D}$-glucose. The solution was supplemented with vitamins and amino acids as in Eagle's Minimal Essential Medium. The $\mathrm{pH}$ was 7.4 and osmolality was $315-325 \mathrm{mmol} / \mathrm{kg}$.

Isolation of hair cells. Both dissociation procedures had an enzymatic and a mechanical component. Enzymes were dissolved in low-Ca ${ }^{2+} \mathrm{L}-15$ for outer hair cells and in vestibular external medium for vestibular hair cells. The enzyme treatment included immersion in solution containing crude papain $(500 \mu \mathrm{g} / \mathrm{ml})$ and $300 \mu \mathrm{g} / \mathrm{ml} \mathrm{L}$-cysteine at $37^{\circ} \mathrm{C}$. This step took $30 \mathrm{~min}$ for cochlear hair cells and 40 60 min for vestibular hair cells. The papain step was followed by immersion in solution containing $500 \mu \mathrm{g} / \mathrm{ml}$ bovine serum albumin (BSA) for $\geq 10 \mathrm{~min}$ at $22-25^{\circ} \mathrm{C}$. Vestibular hair cells had an additional enzyme treatment (below) to ease removal of the otolithic gel and otoconia overlying the bundles.

To obtain outer hair cells, we first exposed the sensory epithelium (organ of Corti) by removing the bony wall of the cochlea and the tectorial membrane. The organ of Corti in the apical turn was peeled off and treated with papain and BSA solutions, as described above. Hair cells in this turn of the rat cochlea at this age have characteristic frequencies $\leq 6 \mathrm{kHz}$ (Muller 1991). The epithelium was then transferred to an experimental chamber containing $200 \mu$ low $\mathrm{Ca}^{2+} \mathrm{L}-15$ medium, and hair cells were mechanically isolated by gentle trituration with a $10-\mu l$ plastic pip- ette tip. Outer hair cells were recognized by their elongated cylindrical shape.

To obtain vestibular hair cells, we opened the otic capsule medially to expose the utricle. The utricle was transferred to vestibular medium containing protease XXVII or XXIV $\left(50 \mu \mathrm{g} / \mathrm{ml}\right.$ for $10 \mathrm{~min}$ at $\left.22-25^{\circ} \mathrm{C}\right)$. This treatment loosened the overlying otoconial membrane, which was then peeled off. The utricular epithelium was treated with papain and BSA solutions, as described above, then transferred to the recording chamber, where hair cells were brushed off the epithelium with a fine probe. We selected type I hair cells for recording by their distinctive amphora shape.

\section{Recording}

The dissociated cells were viewed at $600 \times$ with Nomarski optics on an inverted microscope (Olympus IMT-2, Olympus Corporation, Lake Success, NY). Currents were recorded with the whole-cell variant of the patch clamp method (Hamill et al. 1981) at room temperature $\left(22-25^{\circ} \mathrm{C}\right)$. We used the ruptured-patch method of whole-cell recording for outer hair cells but the perforated-patch method (Horn and Marty 1988) for type I hair cells because $g_{\mathrm{K}, \mathrm{L}}$ 's properties change during ruptured-patch recordings (as discussed in Results). In the perforated-patch method, pore-forming antibiotic molecules permit passage of small monovalent ions but not larger molecules, reducing disruption of internal second messengers. Use of this method reduces drift in the properties of $g_{\mathrm{K}, \mathrm{L}}$.

Outer hair cells. Pipettes were pulled from thinwalled R6 glass (1.5-mm outer diameter; Garner Glass Company, Claremont, CA) and usually filled with a standard $\mathrm{K}^{+}$solution, containing (in $\mathrm{mM}$ ) $160 \mathrm{KCl}$, $3.5 \mathrm{MgCl}_{2}, 0.1 \mathrm{CaCl}_{2}, 5$ HEPES, 10 EGTA, $2.5 \mathrm{Na}_{2}-$ ATP, $0.1 \mathrm{Na}-\mathrm{cAMP}$, and $0.1 \mathrm{Li}_{3}-\mathrm{GTP}$; osmolality 290$310 \mathrm{mmol} / \mathrm{kg}$ and adjusted to $\mathrm{pH} 7.4$ with $25 \mathrm{mM}$ $\mathrm{KOH}$ for a final $\mathrm{K}^{+}$concentration of $160 \mathrm{mM}$. With $5.8 \mathrm{mM} \mathrm{K}^{+}$in the high-Ca ${ }^{2+} \mathrm{L}-15$ recording medium, the equilibrium potential for $\mathrm{K}^{+}\left(E_{\mathrm{k}}\right)$ was $-84 \mathrm{mV}$. In some experiments we used a solution in which $\mathrm{Cs}^{+}$ was substituted for $\mathrm{K}^{+}$. For most recordings, cells were bathed with the high-Ca ${ }^{2+} \mathrm{L}-15$ medium. In several experiments this was replaced by $\mathrm{Cs}^{+}$external medium, similar to the vestibular medium but with all $\mathrm{K}^{+}$ replaced by $\mathrm{Cs}^{+}$. Pipette resistances ranged from 3 to $5 \mathrm{M} \Omega$ in our standard solutions. Voltages are corrected for a liquid junction potential of $-4 \mathrm{mV}$, estimated using JPCalc software (Barry 1994).

Currents were recorded with an EPC-7 patch clamp amplifier (List-Medical, Darmstadt, Germany), and digitized with a 12-bit data acquisition board (DigiData 1200; Axon Instruments, Foster City, CA) 
controlled by pClamp 8.1 software (Axon Instruments). Currents were low-pass filtered at $2-3 \mathrm{kHz}$ with an 8-pole Bessel filter (Frequency Devices, Haverhill, MA) and sampled at over twice the filter frequency. For 300-ms voltage step protocols, (e.g., Figs. 1 and 5) the sampling interval was $10 \mu \mathrm{s}$ throughout the recording. For 3-s voltage step protocols, (e.g., Fig. 2) the sampling interval was $10 \mu \mathrm{s}$ during the tail current and $200 \mu$ s for the rest of the trial.

Linear membrane capacitance and series resistance were taken from the settings of the amplifier's compensation circuitry that nulled the capacitive transients produced by small voltage steps $(2-10 \mathrm{mV})$. We obtained an average linear capacitance of $16 \pm 0.4 \mathrm{pF}$ (SEM; $n=43$ ). Outer hair cells also have considerable gating current (nonlinear capacitance) associated with the electromotile function of their lateral membranes (Ashmore 1990; Santos-Sacchi 1991), which produces uncompensated transients at voltage transitions. Peak nonlinear capacitances for rat outer hair cells of this age (P14) are, on average, $7.5 \mathrm{pF}$ (Oliver and Fakler 1999). Series resistances were compensated with the patch clamp circuitry by $50 \%-60 \%$, leaving residual series resistance $\left(R_{\mathrm{s}}\right)$ values of $8 \pm 2.7 \mathrm{M} \Omega(n=100$ measurements from 43 cells; range $=4.6-20.8 \mathrm{M} \Omega$ ). Therefore, the voltage clamp time constant is, on average, $R_{\mathrm{s}} \times C_{\mathrm{m}}=(8 \mathrm{M} \Omega)$ $\times(16+7.5 \mathrm{pF})=180 \mu \mathrm{s}$. Because this value is $5-50$ fold less that the shortest activation and deactivation time constants that we measured, (See Figs. 3 and 4) the clamp time did not interfere with our kinetic measurements.

Type I vestibular hair cells. Whole-cell currents were recorded using the perforated patch variant of the whole-cell patch clamp method. The pipette solution contained (in $\mathrm{mM}$ ) $196.5 \mathrm{~K}^{+}, 5 \mathrm{Mg}^{2+}, 0.1 \mathrm{Ca}^{2+}, 35.2$ $\mathrm{Cl}^{-}, 80 \mathrm{SO}_{4}{ }^{2-}, 5$ HEPES, 5 EGTA, plus $240 \mu \mathrm{g} / \mathrm{ml}$ Amphotericin B. The $\mathrm{pH}$ was 7.4 and the osmolality was $\sim 280 \mathrm{mmol} / \mathrm{kg}$. With $5.8 \mathrm{mM} \mathrm{K}^{+}$in the external medium, $E_{k}$ was $-89 \mathrm{mV}$. Borosilicate pipettes were pulled and heat-polished to final pipette resistances of between 1.5 and $3 \mathrm{M} \Omega$ in our standard solutions. The calculated junction potential of $9 \mathrm{mV}$ was subtracted from voltages offline.

Currents were recorded with an Axopatch 200A or 200B patch clamp amplifier (Axon Instruments). Series resistance was estimated and compensated $70 \%$ with the intrinsic circuitry of the amplifier. In a sample of 33 cells, the mean uncompensated series resistance was $11 \pm 0.6 \mathrm{M} \Omega$ (range $=4.5-18 \mathrm{M} \Omega$ ) and the mean residual series resistance following compensation $\left(R_{\mathrm{s}}\right)$ was calculated to be $3 \pm 0.2 \mathrm{M} \Omega$ (range $=1.4-5.4 \mathrm{M} \Omega$ ). The average membrane capacitance was $4 \pm 0.2 \mathrm{pF}$ ( $n=33$ cells), yielding an average clamp time constant of $(3 \mathrm{M} \Omega) \times(4$
$\mathrm{pF})=12 \mu \mathrm{s}$. As this was 200-fold faster than the fastest time constant that we measured, (See Fig. 4) the clamp time did not interfere with kinetic measurements. Currents were filtered and sampled as described for outer hair cells.

\section{Analysis}

Analyses and fits were done with Origin software (versions 6.1-7, OriginLab Software, Northampton, MA), which uses a Levenberg-Marquardt leastsquares fitting algorithm. Voltages in activation curves were corrected offline for errors introduced by uncompensated series resistance. Results are shown as means \pm standard errors of the mean (SEM). Mean values were compared with the two-tailed Student's $t$-test, with $p<0.05$ as the criterion for statistical significance.

Activation curves. CThe voltage dependence of steady-state activation was expressed as conductancevoltage (activation) curves. Data for the curves were generated by delivering voltage steps at multiple potentials and measuring the peak tail current at the offset of each step (illustrated in Fig. 2). The tail current is proportional to the activation level reached by the ion channels during the step. Sigmoidal curves were fit with the following Boltzmann function:

$$
I(V)=\frac{I_{\min }-I_{\max }}{1+e^{\left[\left(V-V_{1 / 2}\right) / S\right]}}+I_{\max }
$$

where $I(V)$ is current at voltage $V, I_{\max }$ is maximum current, $V_{1 / 2}$ is voltage corresponding to half-maximal activation, and $S$ is the voltage corresponding to an $e$-fold increase in $I(V)$. In some cells, activation curves had two sigmoidal components and were fit with a sum of Boltzmanns:

$$
I(V)=\frac{I_{\min }-I_{1}}{1+e^{\left(V-V_{1}\right) / S_{1}}}+\frac{I_{1}-I_{2}}{1+e^{\left(V-V_{2}\right) / S_{2}}}+I_{1}+I_{2}
$$

$V_{1}$ and $V_{2}$ are the $V_{1 / 2}$ values, $S_{1}$ and $S_{2}$ are $S$ values, and $I_{1}$ and $I_{2}$ correspond to the maximum currents for each Boltzmann component.

Kinetics. Activation kinetics were characterized with a relatively short delay, followed by a slower activation, and were fit with an equation used previously to fit $g_{\mathrm{K}, \mathrm{L}}$ (Rüsch and Eatock 1996a):

$$
I(t)=I_{\mathrm{SS}}-\frac{\left(I_{\mathrm{SS}}-I_{0}\right)}{\left(\tau_{1}-\tau_{2}\right)}\left(\tau_{1} e^{-t / \tau_{1}}-\tau_{2} e^{-t / \tau_{2}}\right)
$$

where $I(t)$ is the current at time $t, I_{\mathrm{SS}}$ is the steadystate current, $I_{0}$ is the initial current, and $\tau_{1}$ and $\tau_{2}$ are the two time constants. 
The sigmoidal deactivation time course of $g_{\mathrm{K}, \mathrm{n}}$ was also fit with Eq.(3), while deactivation for $g_{\mathrm{K}, \mathrm{L}}$ was fit with the sum of two exponentials:

$$
I(t)=I_{0}+A_{1} e^{-t / \tau_{1}}+A_{2} e^{-t / \tau_{2}}
$$

where $A_{1}$ and $A_{2}$ are the amplitudes of the exponential terms.

\section{RESULTS}

Whole-cell voltage-gated currents were recorded from 43 outer hair cells from the apical turn of the cochlea. The cells had a mean linear membrane capacitance of $16 \pm 0.4 \mathrm{pF}$ (range $=8.9-21.0 \mathrm{pF}$ ). Twenty-eight of the cells were recorded with the $\mathrm{K}^{+}$internal solution and had a mean zero-current potential of $64 \pm 0.8 \mathrm{mV}$ (range $=-58$ to $-76 \mathrm{mV}$ ) in high- $\mathrm{Ca}^{2+} \mathrm{L}-$ 15 ; thus, our holding potential of $-64 \mathrm{mV}$ matched the average resting potential in standard solutions. The remaining 15 cells were recorded with the $\mathrm{Cs}^{+}$ internal solution.

For comparison, we report data from 18 type I hair cells isolated from the rat utricle (P16-P24). Zerocurrent potentials were not routinely measured but were always negative to the holding potential of $69 \mathrm{mV}$, as shown by the outward holding current. The mean linear capacitance of a larger dataset of cells from animals in the same age range was $4 \pm 0.2 \mathrm{pF}$ $(n=33$ cells, range $=2-6 \mathrm{pF})$. Since linear membrane capacitance is proportional to surface area, the type I cells have about one-quarter the surface area of the outer hair cells.

\section{Voltage dependence of activation}

Activation curve for $\boldsymbol{g}_{\mathrm{K}, \mathrm{n}}$. Marcotti and colleagues (1999) reported that during the second and third weeks after birth, outer hair cells in the apical turn of the mouse cochlea may express several voltage-gated conductances. These include an outwardly rectifying conductance with a relatively positive activation range that resembles a $\mathrm{K}^{+}$conductance expressed at earlier stages $\left(g_{\mathrm{K}, n e o}\right)$ plus two conductances that are at least partly activated at the resting potential: a large conductance that is deactivated by strong hyperpolarizations $\left(g_{\mathrm{K}, \mathrm{n}}\right)$ and a small conductance that is further activated with hyperpolarization $\left(g_{\mathrm{K} 1}\right.$, a fast inward rectifier). Figure 1 illustrates these three conductances in a rat outer hair cell recorded in control solutions and in the presence of the KCNQ blocker, linopirdine. Activation curves were generated from tail currents taken at $-34 \mathrm{mV}$ following iterated 300 ms or 3-s voltage steps (see voltage protocols in Figs. 1 and 2), then were fit by single or double Boltzmann functions [Eqs. (1) and (2), Methods]. The fits yiel- ded values for $V_{1 / 2}$, the voltage corresponding to halfmaximal activation, and $S$, the voltage range over which the current increases $\theta$-fold.

In 5 of 28 outer hair cells recorded with $\mathrm{K}^{+}$internal solution, the activation curve had two components. In mouse outer hair cells, Marcotti and Kros (1999) showed that the double Boltzmann activation curve reflects a transitional stage in development, before $g_{\mathrm{K}, \text { neo }}$ has disappeared but after $g_{\mathrm{K}, \mathrm{n}}$ has been acquired. Fits of Eq. (2), the sum of two Boltzmanns, to the five activation curves yielded a mean $V_{1 / 2}$ for the more positive component of $-11.7 \pm 2.02 \mathrm{mV}$ (range $=-17.5$ to $-6.4 \mathrm{mV}$ ) and a mean $S$ value of $5.2 \pm 0.35 \mathrm{mV}$. If we assume that this component is related to $g_{\mathrm{K}, \text { neo }}$ in immature mouse outer hair cells and is therefore $\mathrm{a} \mathrm{K}^{+}$conductance, then the mean peak amplitude of $97 \pm 28.0 \mathrm{pA}$ at $-34 \mathrm{mV}$ gives a maximal conductance of $1.9 \mathrm{nS}\left[g_{\max }=I_{\max } /(V-\right.$ $\left.\left.E_{\mathrm{K}}\right) ; V=-34 \mathrm{mV} ; E_{\mathrm{K}}=-84 \mathrm{mV}\right]$.

The more negatively activating conductance, $g_{\mathrm{K}, \mathrm{n}}$, had a mean $\mathrm{V}_{1 / 2}$ of $-91.2 \pm 1.06 \mathrm{mV}$ (range $=-83.0$ to $-105.9 \mathrm{mV})$ and $S$ value of $12.6 \pm 0.46 \mathrm{mV}(n=24$ cells; the five cells above plus 19 cells with activation curves well fit by a single Boltzmann). These values agree closely with the original description by Housley and Ashmore (1992). The mean peak amplitude of the fits to tail currents $\left[I_{\max }, \mathrm{Eq} .(1)\right]$ was $335 \pm 43.7$ $\mathrm{pA}$, similar to the value for mouse apical outer hair cells in the same age range (Marcotti and Kros 1999) and corresponding to a $g_{\max }$ of $6.8 \mathrm{nS}$.

Pharmacological isolation of $\boldsymbol{g}_{\mathrm{K}, \mathrm{n}}$. To isolate $g_{\mathrm{K}, \mathrm{n}}$, we added $10 \mu \mathrm{M}$ linopirdine to the high- $\mathrm{Ca}^{2+}$ external solution (Fig. 1B). This dose is considered to be selective for KCNQ channels (Wang et al. 1998) and blocks more than $95 \%$ of the current that is deactivated by stepping from -84 to $-124 \mathrm{mV}$ in mouse outer hair cells (Marcotti and Kros 1999). In the cell in Figure 1, linopirdine spared $g_{\mathrm{K}, \text { neo }}\left(V_{1 / 2}=\right.$ $-12.5 \mathrm{mV})$ and much of $g_{\mathrm{K} 1}\left(V_{1 / 2}=-72.0 \mathrm{mV}\right)$. In six cells studied with linopirdine, the mean $V_{1 / 2}$ and $S$ values of the linopirdine-sensitive current (Fig. 1D) were $-93.0 \pm 3.24 \mathrm{mV}$ and $13.4 \pm 1.53 \mathrm{mV}$, indistinguishable from the values obtained by fitting control data over the voltage range -124 to $-44 \mathrm{mV}$. Thus, $g_{\mathrm{K}, \mathrm{n}}$ dominated $g_{\mathrm{K} 1}$ in the whole-cell activation curve over this voltage range. $g_{\mathrm{K} 1}$ contributed to the pedestal of current at $-124 \mathrm{mV}$, a voltage at which $g_{\mathrm{K}, \mathrm{n}}$ was largely deactivated. Linopirdine reduced the current at $-124 \mathrm{mV}$, however, suggesting that linopirdine also partly blocks $g_{\mathrm{K} 1}$ at this dosage.

The total block of $g_{\mathrm{K}, \mathrm{n}}$ by $10 \mu \mathrm{M}$ linopirdine stands in marked contrast to its effects on $g_{\mathrm{K}, \mathrm{L}}$ in mature gerbil and pigeon type I hair cells (Rennie et al. 2001), These effects are both weaker and more complex. Linopirdine $(10 \mu \mathrm{M})$ blocked the conductance at -70 to $-80 \mathrm{mV}$ by a small amount but had no effect on 

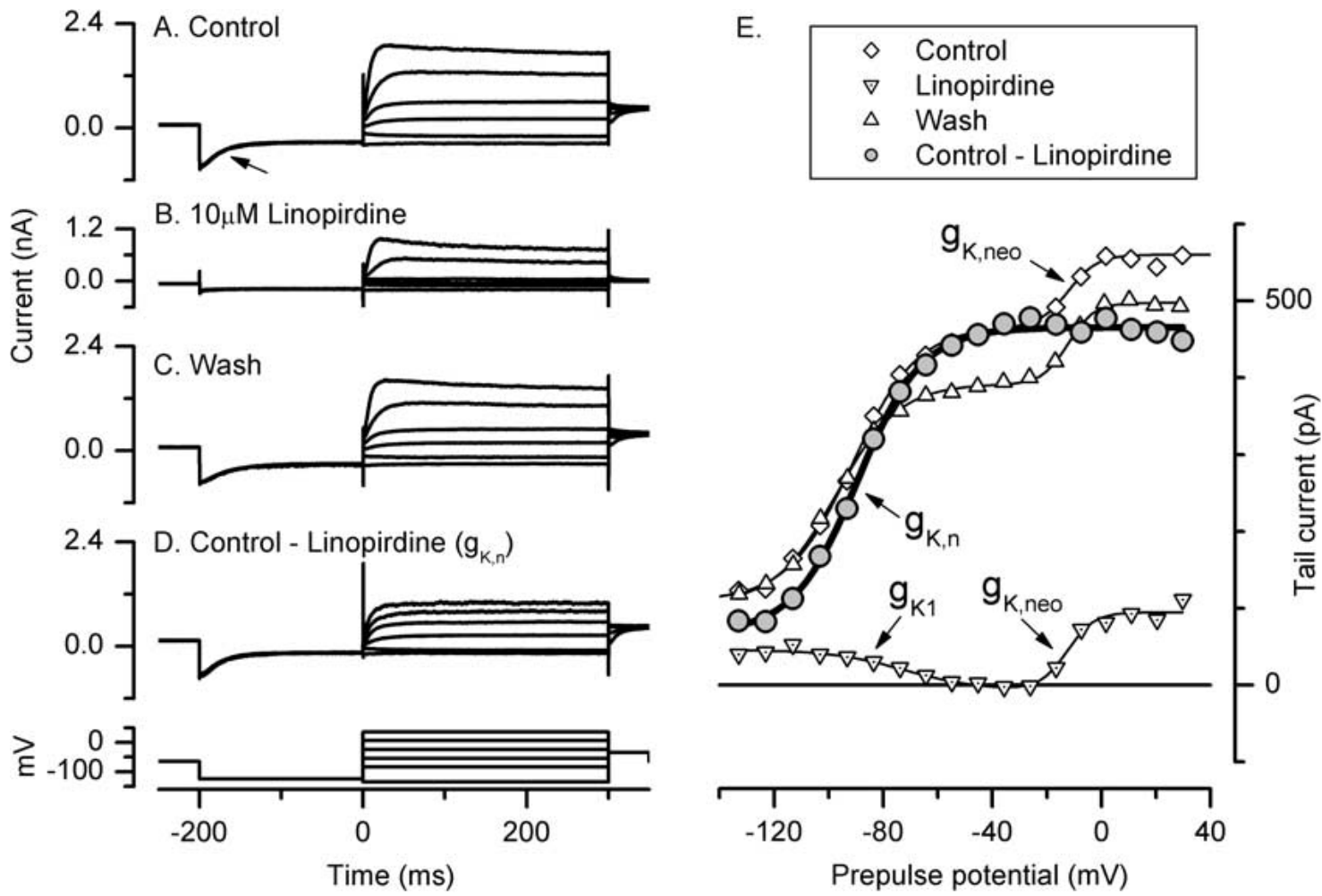

FIG 1. $g_{K, n}$ and other voltage-dependent currents in a rat outer hair cell, revealed by their voltage dependence and sensitivity to the KCNQ blocker, linopirdine. Whole-cell currents were recorded from an outer hair cell isolated from the apical turn of a P17 rat cochlea. A-C Whole-cell currents evoked by the voltage protocol shown below, in control solution (high-Ca $\left.{ }^{2+} \mathrm{L} 15\right)(\mathbf{A})$, control $+10 \mu \mathrm{M} \mathrm{li}$ nopirdine (B) and wash (high-Ca ${ }^{2+}$ L15) (C). Voltage protocol shown at the bottom. From the holding potential of $-64 \mathrm{mV}$, voltage was stepped to $-124 \mathrm{mV}$, which in control solutions deactivated $g_{K, n}$ $(\mathbf{A}, \mathbf{C})$ (arrow in A), and then to a series of steps between -134 and + $36 \mathrm{mV} ; g_{\kappa, n}$ was reactivated by steps positive to $-124 \mathrm{mV}$. At the offset of the iterated voltage steps, the voltage was stepped to $34 \mathrm{mV}$ and peak tail currents were measured. These currents, which reflect the activation state of the channels at the end of the preceding voltage steps, are plotted as functions of the prepulse voltage in $\mathbf{E}$.

steady-state outward currents. Linopirdine $(200 \mu \mathrm{M})$ blocked inward currents by $20 \%-40 \%$ but again had very little effect on outward currents. A more potent KCNQ blocker, XE991, did not affect steady-state outward currents but blocked steady-state inward currents by $\sim 50 \%$. We have obtained similar results with both linopirdine and XE991 on $g_{\mathrm{K}, \mathrm{L}}$ in rat utricular type I cells (unpublished results).

Comparison with the activation curve for $g_{\mathrm{K}, \mathrm{L}}$. Figure 2 compares the activation curves of $g_{\mathrm{K}, \mathrm{n}}$ and $g_{\mathrm{K}, \mathrm{L}} \cdot g_{\mathrm{K}, \mathrm{L}}$ had a narrower operating range $(S=6.0 \pm 0.56 \mathrm{mV}$, $n=18)$ and more positive $V_{1 / 2}(-80.4 \pm 1.90 \mathrm{mV})$ than $\operatorname{did} g_{\mathrm{K}, \mathrm{n}}$. These values from perforated-patch recordings of rat utricular type I cells agree with values obtained from ruptured-patch recordings of rodent type I cells. $S=5.4 \pm 0.19 \mathrm{mV}$ in 57 mouse utricular cells (Rüsch and Eatock 1996a),

Linopirdine (B) blocked the current component that deactivated during the hyperpolarizing step (arrow in A), and much of the current during the iterated voltage steps. D. The linopirdine-blocked current (through $g_{\kappa, n}$ ), obtained by subtracting records in B from records in A. E. Activation curves generated from tail currents at the offset of the iterated voltage steps; the tail current voltage was $-34 \mathrm{mV}$. In control and wash, the curves are fit by the sum of two Boltzmanns [Eq.(2)], with $V_{1 / 2}$ and $S$ values of $-91.3 \mathrm{mV}$ and $11.9 \mathrm{mV}$, respectively, and $12.0 \mathrm{mV}$ and $5.3 \mathrm{mV}$ (control data). Linopirdine fully blocked $g_{\mathrm{K}, \mathrm{n}}$ partly blocked (see text) an inwardly rectifying conductance $\left(g_{\mathrm{K} 1}\right.$; $V_{1 / 2}=-73.5 \mathrm{mV}, S=11.3 \mathrm{mV}$ ), and did not affect the more positively activating outward rectifier $\left(g_{\mathrm{K}, \text { neo }}, \mathrm{V}_{1 / 2}=-13.25 \mathrm{mV}\right.$, $S=3.7 \mathrm{mV})$. The linopirdine-sensitive activation curve $\left(g_{\mathrm{K}, \mathrm{n},}\right.$ from D) is well fit by a single Boltzmann with $\mathrm{V}_{1 / 2}=-89.4 \mathrm{mV}$ and $S=12.2 \mathrm{mV}$.

$4.8 \pm 0.9 \mathrm{mV}$ in 35 rat semicircular canal cells (Chen and Eatock 2000), and $4.9 \pm 0.20 \mathrm{mV}$ in 20 rat utricular cells (M. Saeki and R.A. Eatock, unpublished). $V_{1 / 2}$ had a mean value of $-74 \pm 1.6 \mathrm{mV}$ in 35 rat semicircular canal cells (Chen and Eatock 2000) but was not normally distributed in the utricular cells; rather, it varied broadly between -50 and $-90 \mathrm{mV}$ (Rüsch and Eatock 1996a; M. Saeki and R.A. Eatock, unpublished).

Some of the variability in $V_{1 / 2}$ values reported for $g_{\mathrm{K}, \mathrm{L}}$ reflects variation with time during rupturedpatch recordings (Rennie and Correia 1994; Rüsch and Eatock 1996a; Chen and Eatock 2000). In one example, the activation curve for $g_{\mathrm{K}, \mathrm{L}}$ shifted $+24 \mathrm{mV}$ with a time constant of 26 min (See Fig. 4 in Chen and Eatock 2000). In contrast, we found that $g_{\mathrm{K}, \mathrm{n}}$ 's activation curve did not change with time following 
A. $g_{K, n}(\mathrm{OHC})$

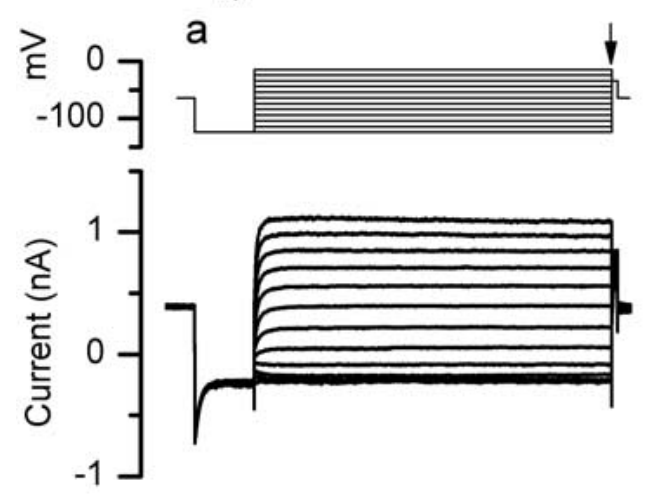

B. $g_{K, L}($ Type I)

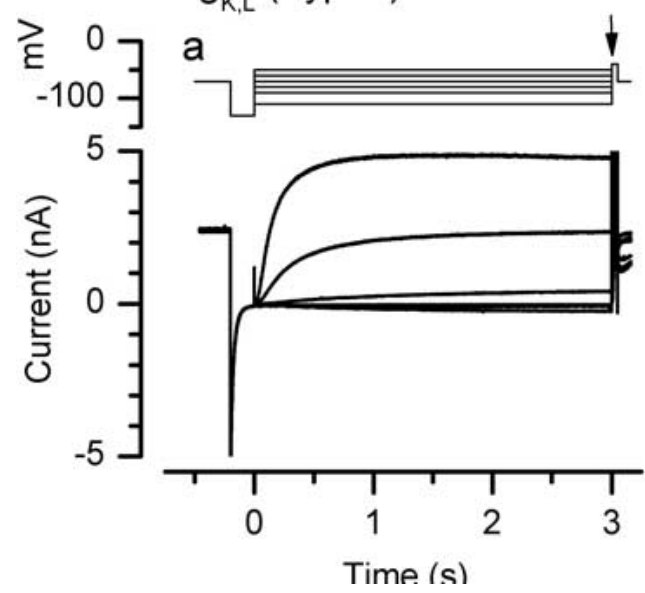

FIG. 2. Differences in the voltage dependences of $g_{K, n}$ and $g_{K, L}$. Whole-cell currents were recorded from a P16 outer hair cell (Aa) and a P17 type I cell (Ba) with 3-s voltage step protocols (top panels). Aa. Steps to $-124 \mathrm{mV}$ from a holding potential of $-64 \mathrm{mV}$ deactivated $g_{K, L}$. Ba. Steps to $-129 \mathrm{mV}$ from a holding potential of $-69 \mathrm{mV}$ deactivated $g_{K, L}$. Depolarizing steps reactivated the conductances. $\mathbf{A b}, \mathbf{B b}$. At the offset of the iterated voltage steps, the voltage was stepped to $-34 \mathrm{mV}$ (Aa) and $-39 \mathrm{mV}$ (Ba) and tail currents were measured (at the arrows) for plotting against prepulse voltage in $\mathbf{c}$. Ac, Bc. Activation curves for the tail current data shown in $\mathbf{A b}, \mathbf{B b}$ (filled circles) are fit with a Boltzmann function [Eq.(1) thick lines, yielding

the onset of ruptured-patch recording. In paired comparisons, activation curves taken at the onset of recording and 10-30 min later were not significantly different: mean $V_{1 / 2}$ values were $-91.2 \pm 2.20$ and $91.8 \pm 2.47 \mathrm{mV}(n=8$ cells; mean interval between activation curves: $17.5 \mathrm{~min}$, range $=10-32)$.

\section{Kinetics}

Activation kinetics. The activation and deactivation time courses of $g_{\mathrm{K}, \mathrm{n}}$ were fit originally with monoexponential functions (Housley and Ashmore 1992). Close inspection of our records revealed that the time

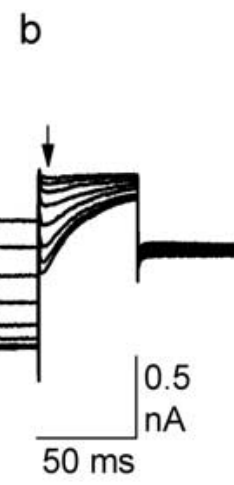

b
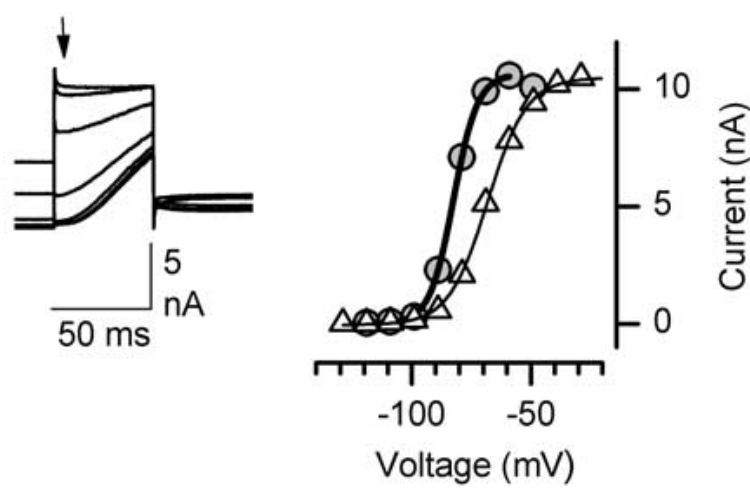

$V_{1 / 2}$ and $S$ values of $-93.6 \mathrm{mV}$ and $12.4 \mathrm{mV}\left(\mathbf{A C}, g_{\mathrm{K}, \mathrm{n}}\right)$ and $-82.4 \mathrm{mV}$ and $5.0 \mathrm{mV}\left(\mathbf{B C}, g_{K, L}\right)$, near the mean values for our samples of outer hair cells and type I hair cells, respectively. In this outer hair cell, unlike the cell in Figure 1, the activation curve is well fit by a single Boltzmann, with no indication of a second outward rectifier at depolarized potentials. This is not related to the long-duration iterated voltage steps, as a similar activation curve was obtained with 300-ms voltage steps (Ac, (triangles and thin line: $\mathrm{V}_{1 / 2}$ and $S$ values of $-92.8 \mathrm{mV}$ and $12.3 \mathrm{mV}$ ). In the type I cell, in contrast, the activation curve taken after 300-ms voltage steps (triangles) was positively shifted (thin line): $V_{1 / 2}=-68.1 \mathrm{mV}$ and $S=8.19 \mathrm{mV}$.

course was sigmoidal, i.e., activation (and deactivation, see next section) followed a brief delay. We therefore fit the activation of $g_{\mathrm{K}, \mathrm{n}}$ with Eq. (3) (Fig. 3A), which we have previously used to fit the sigmoidal activation of $g_{\mathrm{K}, \mathrm{L}}$ (Rüsch and Eatock 1996a). An example of fits of Eq. (3) to $g_{\mathrm{K}, \mathrm{L}}$ activation is shown in Figure 3B. Averaged fast and slow time constants from such fits are separately plotted as functions of voltage in Figures $3 \mathrm{D}$ and $3 \mathrm{E}$, respectively. Over most of the voltage range the time constants of outer and type I hair cells differed significantly. As the membrane voltage changed from approximately -30 to $-90 \mathrm{mV}$, mean fast time constants for $g_{\mathrm{K}, \mathrm{n}}$ increased from 1 to $7 \mathrm{~ms}$ while those 


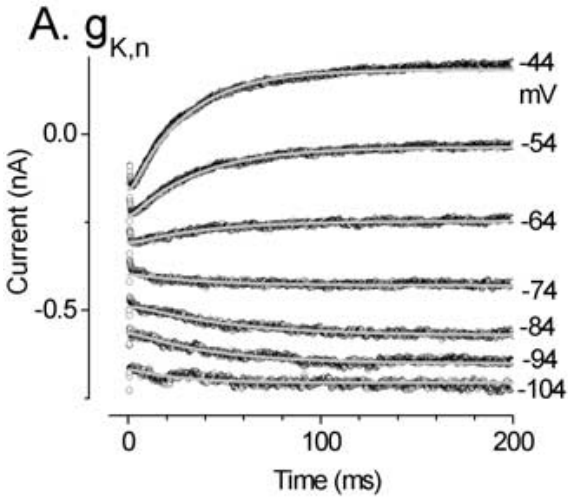

B. $g_{\mathrm{K}, \mathrm{L}}$

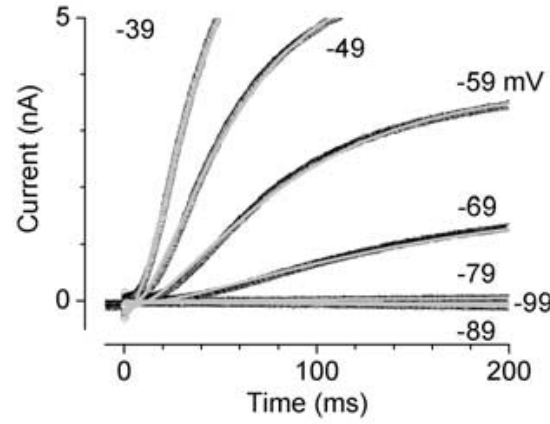

C. $g_{K, n}$ vs. $g_{K, L}$

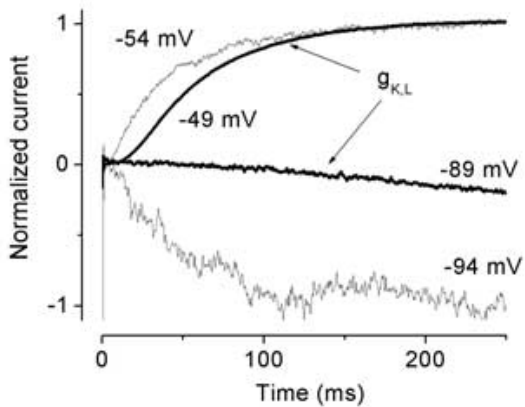

FIG. 3. Differences in the activation kinetics of $g_{K, n}$ and $g_{K, L}$. A,B. Fitting of activation kinetics with Eq.(3) for $(\mathbf{A}) g_{K, n}$ from a P16 outer hair cell and (B) $g_{K, L}$ from a P19 type I hair cell. Voltage was first stepped to $-124 \mathrm{mV}$ for $500 \mathrm{~ms}$ (A) and $-129 \mathrm{mV}$ for $200 \mathrm{~ms}$ (B) to fully deactivate the conductances, then stepped to the values indicated by each trace. $g_{K, n}: V_{1 / 2}=-87.5, S=14.1 \mathrm{mV}$, no second outward rectifier, average of 3 traces at each voltage; $g_{\mathrm{K}, \mathrm{L}}: V_{1 / 2}=$ $-83.6, S=5.0 \mathrm{mV}$, not averaged. C. Currents from $\mathbf{A}$ and $\mathbf{B}$ at two similar command voltages, normalized to the current at $3 \mathrm{~s}$ for

for $g_{\mathrm{K}, \mathrm{L}}$ increased from 12 to $120 \mathrm{~ms}$. Thus, $g_{\mathrm{K}, \mathrm{n}}$ activated with a significantly shorter delay (see comparison of normalized currents in Fig. 3C). The slow time constants overlapped positive to $-30 \mathrm{mV}$, but as voltage became more negative they diverged, with maxima of $\sim 1200 \mathrm{~ms}$ at $-79 \mathrm{mV}\left(g_{\mathrm{K}, \mathrm{L}}\right)$ and $100 \mathrm{~ms}$ at $-94 \mathrm{mV}\left(g_{\mathrm{K}, \mathrm{n}}\right)$.

\section{Fast time constants}

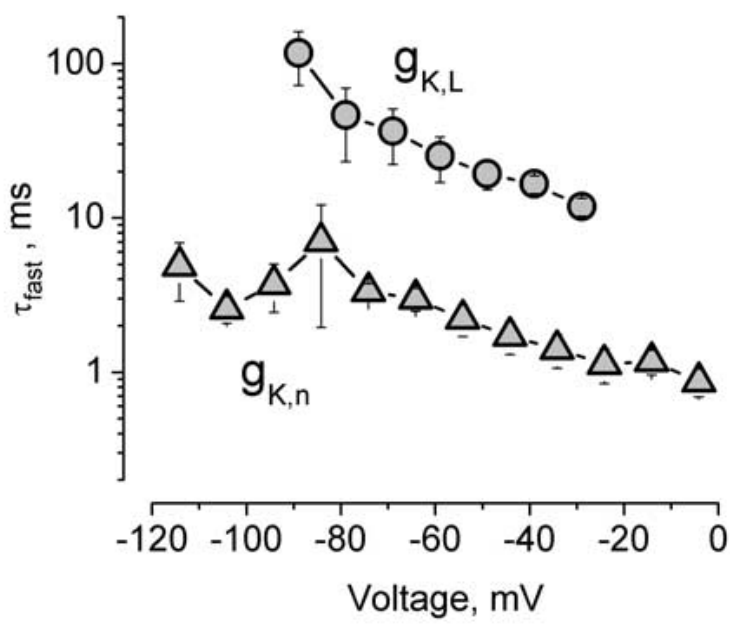

\section{E. Slow time constants}

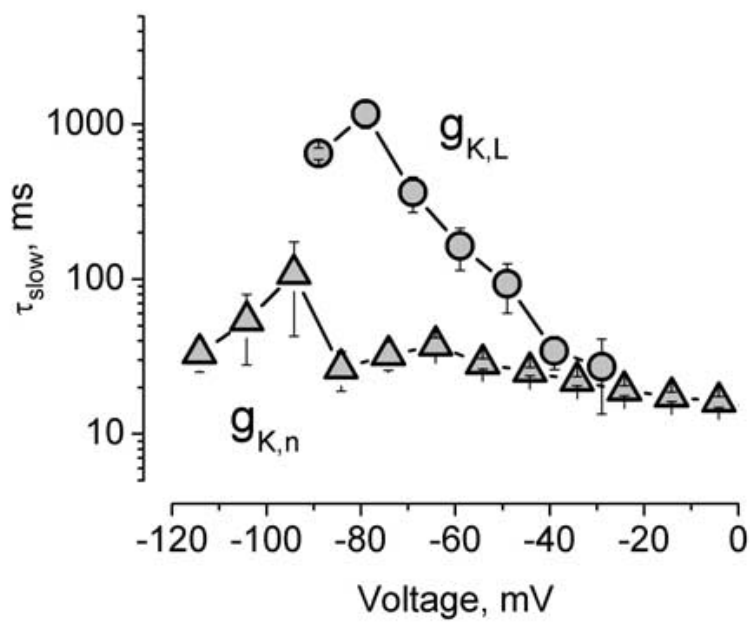

comparison of kinetics. $g_{\mathrm{K}, \mathrm{L}}$ activated much more slowly at voltages near $-90 \mathrm{mV}$ and with a longer delay at voltages near $-50 \mathrm{mV}$. Note that the reversal potentials for these $\mathrm{K}^{+}$conductances were approximately $-80 \mathrm{mV}$, so that current was inward at $-90 \mathrm{mV}$ and outward at $-50 \mathrm{mV}$. D,E. Fast (D) and slow (E) time constants as functions of voltage. Triangles values for $g_{\mathrm{K}, \mathrm{n}}$ averaged from 5 OHCs. Circles, values for $g_{\mathrm{K}, \mathrm{L}}$ averaged from 4-5 type I hair cells, except for the data points at $-29 \mathrm{mV}$, which are averages of fits from two cells $\left(\tau_{\text {slow }}=13.4,27.2 \mathrm{~ms} ; \tau_{\text {fast }}=13.4,11.9 \mathrm{~ms}\right)$.

The large size of $g_{\mathrm{K}, \mathrm{L}}$ raises concerns about the effects of imperfect voltage clamp on measured kinetics. However, the slowest time constants (Fig. 3C) were obtained under conditions when voltage clamp errors should be minimal: following the hyperpolarizing prepulse, which, by shutting off $g_{\mathrm{K}, \mathrm{L}}$, greatly increased input resistance and minimized 
current flow, and during steps to voltages near $E_{\mathrm{K}}$, where currents are small.

Because of the slow time course of $g_{\mathrm{K}, \mathrm{L}}$ near $V_{1}$, 2 , voltage steps longer than $1 \mathrm{~s}$ were needed for an activation curve that was truly steady state (Fig. 2B). Shorter voltage steps produced a shifted $V_{1 / 2}$ estimate, with the direction of the shift determined by whether a hyperpolarizing step preceded the iterated voltage steps. A hyperpolarizing prepulse deactivated $g_{\mathrm{K}, \mathrm{L}}$, which did not fully reactivate during 300-ms steps for voltage steps near $V_{1 / 2}$; thus, the $V_{1 / 2}$ estimate was shifted positively from its true value (Fig. 2Bc). Without a hyperpolarizing prepulse, $g_{\mathrm{K}, \mathrm{L}}$ was substantially activated at the holding potential and did not fully deactivate in $300 \mathrm{~ms}$ for voltage steps near $V_{1 / 2}$, shifting the $V_{1 / 2}$ estimate negatively (not shown). These data suggest that published activation curves and $I-V$ relations for $g_{\mathrm{K}, \mathrm{L}}$ may not represent steady state, as they were collected with voltage steps that were often less than $1 \mathrm{~s}$ and sometimes much less (e.g., Rennie and Correia 1994; Rüsch and Eatock 1996a,b; Brichta et al. 2002; Chen and Eatock 2000; Masetto et al. 2000).

For $g_{\mathrm{K}, \mathrm{n}}$, activation and deactivation were fast enough that activation curves generated with $300-\mathrm{ms}$ and 3-s voltage steps did not differ significantly $(n=5$ cells, paired $t$-tests; Fig. 2Ac). For 300-ms and 3-s steps, respectively, mean $V_{1 / 2}$ values were $-93.8 \pm 3.50 \mathrm{mV}$ and $-92.3 \pm 2.67 \mathrm{mV}$ and mean $S$ values were $12.7 \pm 0.88 \mathrm{mV}$ and $13.1 \pm 2.26 \mathrm{mV}$.

Deactivation kinetics. $g_{\mathrm{K}, \mathrm{L}}$ deactivates with a doubleexponential time course, whether recorded with the ruptured-patch method (Ricci et al. 1996; Rüsch and Eatock 1996a) or the perforated-patch method (Fig. 4). Deactivation of $g_{\mathrm{K}, \mathrm{n}}$, in contrast, had a slower and sigmoidal onset (Fig. 4). We observed sigmoidal deactivation in both control records and in linopirdine-sensitive currents. It is unlikely that inward rectifier contamination causes the sigmoidal appearance because we saw sigmoidal deactivation in a hair cell lacking $g_{\mathrm{K} 1}$. Sigmoidal deactivation can also be seen in published records of $g_{\mathrm{K}, \mathrm{n}}$, (e.g., Fig. 3 in Housley and Ashmore 1992; Fig. 4 in Santos-Sacchi et al. 1997).

Sigmoidal deactivation is consistent with the channel having to progress through multiple open states before entering a closed state. The hyperpolarization-activated conductance, $g_{\mathrm{h}}$, also shows sigmoidal deactivation (DiFrancesco et al. 1986; Holt and Eatock 1995). Although $g_{\mathrm{h}}$ is found in some hair cells (Holt and Eatock 1995; Sugihara and Furukawa 1996; Rüsch and Eatock 1996b), it has not been described in outer hair cells. Even if $g_{\mathrm{h}}$ were present, it would activate at voltages that deactivate $g_{\mathrm{K}, \mathrm{n}}$.
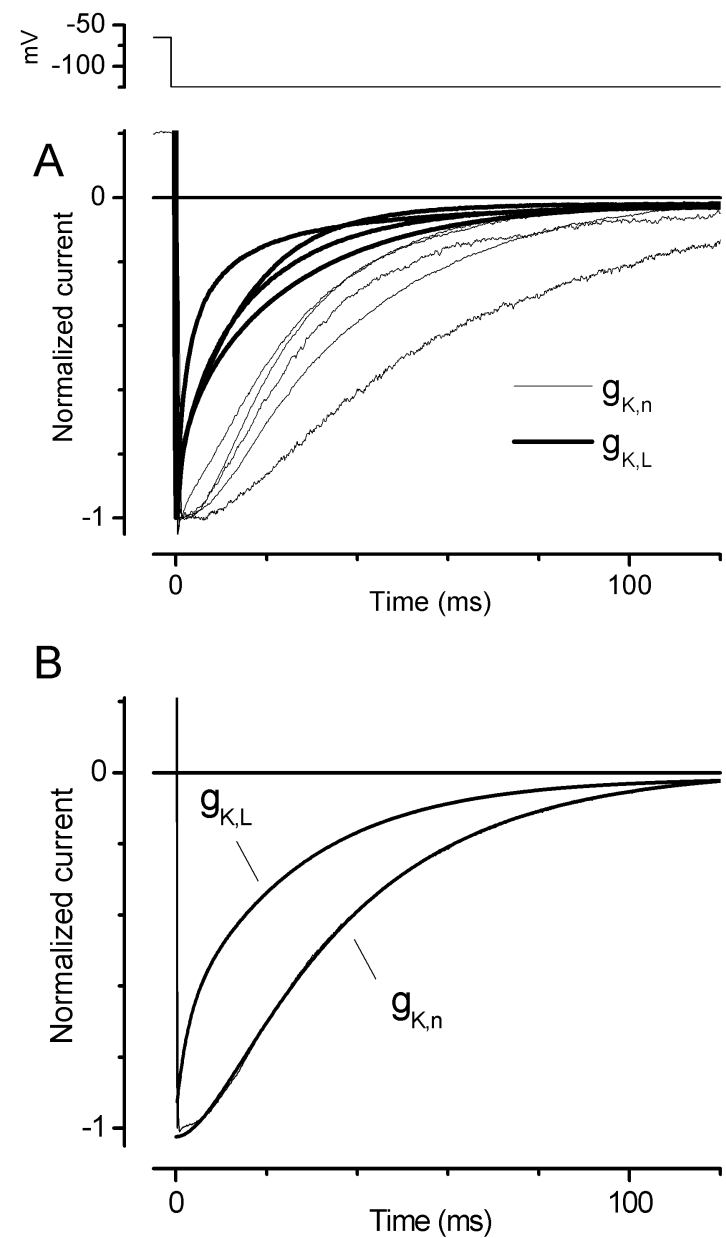

FIG. 4. Differences in the deactivation kinetics of $g_{K, \mathrm{n}}$ and $g_{K, \mathrm{~L}} \cdot g_{\mathrm{K}, \mathrm{L}}$ deactivation followed a single- or double-exponential decay function, while $g_{K, n}$ deactivation had a sigmoidal onset. A. Steps from -64 to $-124 \mathrm{mV}\left(g_{\mathrm{K}, \mathrm{n}}\right)$ or -69 to $-129 \mathrm{mV}\left(g_{\mathrm{K}, \mathrm{L}}\right)$ caused deactivation of currents through both $g_{\mathrm{K}, \mathrm{n}}$, and $g_{\mathrm{K}, \mathrm{L}}$; thin traces are for $g_{\mathrm{K}, \mathrm{n}}$ from 5 outer hair cells, thick traces are for $g_{\mathrm{K}, \mathrm{L}}$ from 5 type I cells. Currents are normalized to the peak current at the beginning of the step. B. Fits (thick lines) to the deactivation of two of the data traces in $\mathbf{A}$ (thin lines; obscured by fits except at the step onset). The type I data were fit by a double-exponential function [eq.(4)]: $A_{1}=-264 \mathrm{pA}$, $\tau_{1}=2.5 \mathrm{~ms}, A_{2}=-684 \mathrm{pA}, \tau_{2}=26.8 \mathrm{~ms}$. The OHC data were fit by Eq.(3): $\tau_{1}=7.8 \mathrm{~ms}, \tau_{2}=33.1 \mathrm{~ms}$.

\section{Cesium permeability}

Internal $\mathrm{Cs}^{+}$substantially blocks many $\mathrm{K}^{+}$channels, but not $g_{\mathrm{K}, \mathrm{L}}$ (Griguer et al. 1993; Rennie and Correia 1994; Rüsch and Eatock 1996a; Chen and Eatock 2000). Figure 5E shows that when $\mathrm{Cs}^{+}$was substituted for $\mathrm{K}^{+}$in the internal solution, $g_{\mathrm{K}, \mathrm{L}}$ carried large currents in either direction. In contrast, $g_{\mathrm{K}, \mathrm{n}}$ passed only inward current under these conditions (Fig. 5B). The net whole-cell currents reversed at about $0 \mathrm{mV}$, corresponding to a permeability ratio for $\mathrm{Cs}^{+}$and $\mathrm{K}^{+}$ $\left(P_{\mathrm{Cs}} / P_{\mathrm{K}}\right)$ of 0.04 (from the Goldman-Hodgkin-Katz equation and assuming negligible $\mathrm{Na}^{+}$permeation).

Comparison of Figures 5B and 5E suggests that internal $\mathrm{Cs}^{+}$can flow out through $g_{\mathrm{K}, \mathrm{L}}$ channels but 


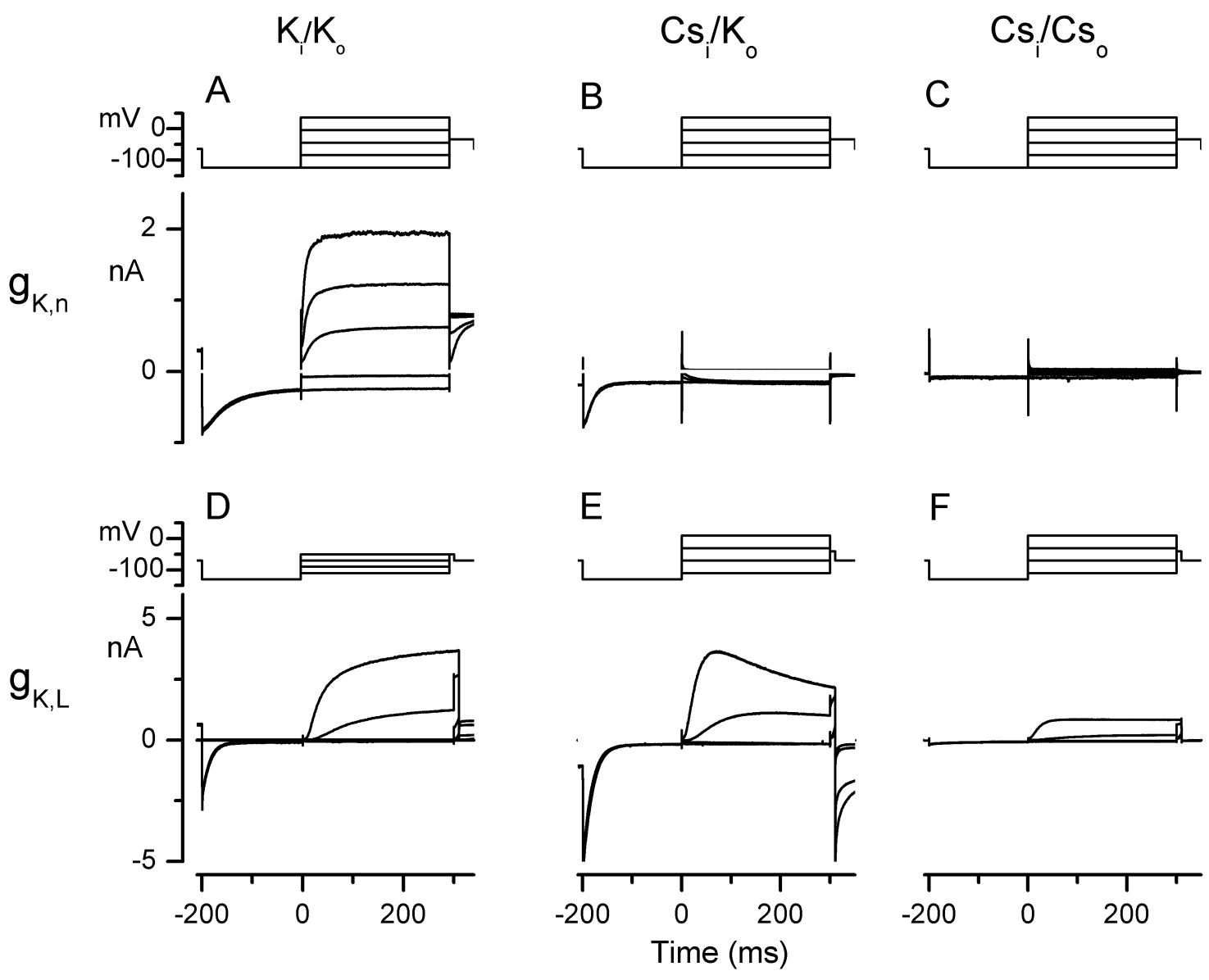

FIG. 5. $g_{K, \mathrm{~L}}$, but not $g_{\mathrm{K}, \mathrm{n}}$, is $\mathrm{Cs}^{+}$permeable. Left column: Currents in control conditions, with high internal $\mathrm{K}^{+}$and 5.8-mM external $\mathrm{K}^{+}$. Middle column (different cells): With an internal $\mathrm{Cs}^{+}$solution, $g_{K, n}$ (B) carried only inward current but $g_{K, L}(\mathbf{E})$ still passed both inward and outward current. Right column (same cells as middle column): When, in addition, external $\mathrm{K}^{+}$was replaced with $\mathrm{Cs}^{+}$, all current through $g_{\kappa, n}$ was blocked $(\mathbf{C}$; residual slope conductance $=600 \mathrm{pS}$ )

not $g_{\mathrm{K}, \mathrm{n}}$ channels. However, Rennie and Correia (2000) found that when they recorded from type I cells with a high $-\mathrm{Na}^{+} / 0-\mathrm{K}^{+}$pipette solution and a standard external medium, $\mathrm{K}^{+}$entering the cell through $g_{\mathrm{K}, \mathrm{L}}$ channels led to $\mathrm{K}^{+}$accumulation inside the cell (" $\mathrm{K}^{+}$loading"). It therefore seemed likely that some of the outward current in our $\mathrm{Cs}_{\mathrm{i}} / \mathrm{K}_{\mathrm{o}}$ recordings from type I cells (Fig. 5E) was carried by $\mathrm{K}^{+}$that had entered the cell at the holding potential and during hyperpolarizing voltage steps. [In the example in Figure 6, 1 nA of inward current flowed at the holding potential of $-69 \mathrm{mV}$ for the 10 -s intertrial interval. If the inward holding current were carried entirely by $\mathrm{K}^{+}$, and we make the unrealistic assumption that there was no equilibration with the pipette solution, then the holding current would increase the $\mathrm{K}^{+}$concentration in the cell (volume $\sim 1$ $\mathrm{pl}$ ) to $\sim 100 \mathrm{mM}$ during the intertrial interval, shifting $E_{\mathrm{K}}$ negatively to approximately $\left.-70 \mathrm{mV}\right]$. During but outward current still flowed in the type I cell (F). Current and voltage axes on the left apply to all panels in a row. In standard solutions, relatively small voltage steps applied to the type I cell (D) elicited very large currents through $g_{K, \mathrm{~L}}$. Currents are from a P16 $\mathrm{OHC}(\mathbf{A})$, a P17 OHC (B,C), a P24 type I cell (D), and a P23 type I cell $(\mathbf{E}, \mathbf{F})$.

subsequent depolarizing voltage steps, some of the outward current would be carried by the accumulated $\mathrm{K}^{+}$until it was depleted. Consistent with this interpretation, there was a shift in the current's reversal potential from about $-65 \mathrm{mV}$ early in the 3-s voltage step (arrow b in Fig. 6) to about $-40 \mathrm{mV}$ late in the step (arrow c in Fig. 6). The decay of the outward current during the steps positive to $-65 \mathrm{mV}$ may reflect the change in $\mathrm{K}^{+}$driving force as the accumulated intracellular $\mathrm{K}^{+}$depletes.

If we suppose that by the end of 3-s depolarizing steps (arrow c in Fig. 6) the internal $\mathrm{K}^{+}$in the vicinity of the channels had decayed to the level in the pipette solution $(0 \mathrm{mM})$, then a reversal potential of $-40 \mathrm{mV}$ corresponds to $P_{\mathrm{Cs}} / P_{\mathrm{K}}=0.15$. This is half of a previous estimate based on the reversal potential of $g_{\mathrm{K}, \mathrm{L}}$ when voltage was stepped from $-64 \mathrm{mV}$ [ruptured-patch recording, $\mathrm{Cs}^{+}$pipette solution, standard external $\mathrm{K}^{+}$(Rüsch and Eatock 1996a)]. In that study, 


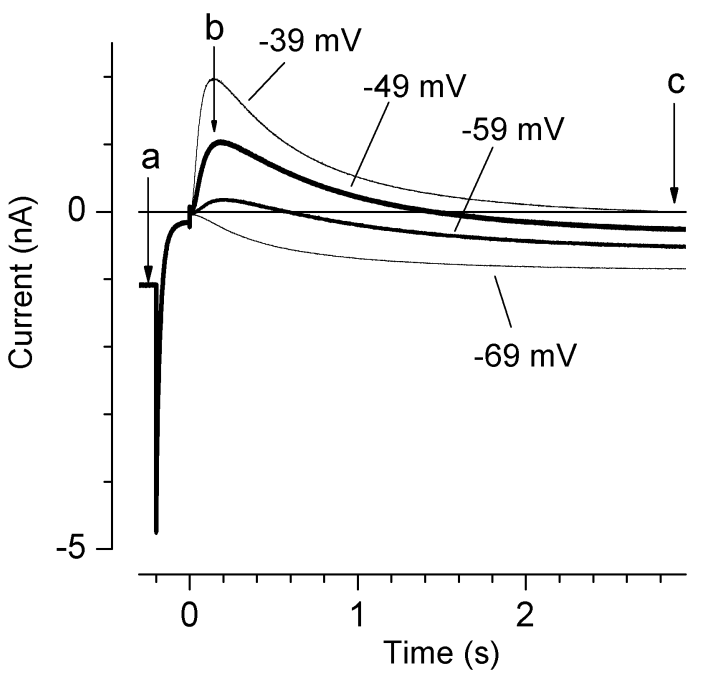

FIG. 6. Changes in the reversal potential of $g_{K, L}$ during long voltage steps may result from significant $\mathrm{K}^{+}$flux through $g_{K, L}$. Standard vestibular external medium and $\mathrm{Cs}^{+}$pipette solution for perforated patch recordings. Same cell as in Figure 5B,C. After a 200-ms step to $-129 \mathrm{mV}$, the peak currents (b, arrow) reversed at approximately $-65 \mathrm{mV}$. With time during 3-s steps positive to $-69 \mathrm{mV}$, however, the reversal potential shifted positively, reaching approximately $-40 \mathrm{mV}$ at the end of the steps (c). The change in reversal potential is shown clearly by the reversal of current polarity during the steps at -59 and $-49 \mathrm{mV}$ (thick traces).

as in the present one, it is possible that $\mathrm{K}^{+}$influx through open $g_{\mathrm{K}, \mathrm{L}}$ channels at $-64 \mathrm{mV}$ led to appreciable $\mathrm{K}^{+}$levels on the cytoplasmic side of the channels. Without an accurate value for intracellular $\mathrm{K}^{+}$ concentration, we cannot be certain of the true $P_{\mathrm{Cs}} /$ $P_{\mathrm{K}}$ value. The 0.15 value is similar to $P_{\mathrm{Cs}} / P_{\mathrm{K}}$ estimates for neuronal M channels (Cloues and Marrion 1996; Block and Jones 1996) and heterologously expressed KCNQ4 channels (Kubisch et al. 1999).

Relative to $g_{\mathrm{K}, \mathrm{n}}$, the maximum current amplitude of $g_{\mathrm{K}, \mathrm{L}}$ in standard recording conditions (Figs. 2 and $5 \mathrm{~A}, \mathrm{D})$ was larger by as much as an order of magnitude, although the type I cells had just one-quarter the membrane surface area of the outer hair cells. Thus, $g_{\mathrm{K}, \mathrm{L}}$ channels were present at much higher density than were $g_{\mathrm{K}, \mathrm{n}}$ channels; Chen and Eatock (2000) estimated $g_{\mathrm{K}, \mathrm{L}}$ channel density to be $\sim 150$ channels $/ \mu \mathrm{m}^{2}$ in type I cells from rat semicircular canals. We were concerned that the difference between $g_{\mathrm{K}, \mathrm{n}}$ and $g_{\mathrm{K}, \mathrm{L}}$ in the outward current under $\mathrm{Cs}_{\mathrm{i}} /$ $\mathrm{K}_{\mathrm{o}}$ conditions reflected a difference in $\mathrm{K}^{+}$loading rather than a difference in $\mathrm{Cs}^{+}$permeability. To eliminate $\mathrm{K}^{+}$loading, we replaced external $\mathrm{K}^{+}$with $\mathrm{Cs}^{+}$(Fig. 5C,F). This change eliminated inward but not outward current in type I cells (Fig. $5 \mathrm{~F}$ ); the outward current must have been carried by $\mathrm{Cs}^{+}$. In outer hair cells, in contrast, almost all current was blocked (Fig. 5C). The mean residual conductance in six outer hair cells was $1.6 \pm 0.44 \mathrm{nS}$.
The block of inward current through $g_{\mathrm{K}, \mathrm{L}}$ in $\mathrm{Cs}_{\mathrm{i}} /$ $\mathrm{Cs}_{\mathrm{o}}$ conditions (Fig. 5F) was somewhat unexpected. In experiments on type I cells in which $\mathrm{Cs}^{+}$was the only external cation (Rennie and Correia 2000), there was significant inward current. Thus, in our experiments in which the external solution contained $5.8 \mathrm{mM} \mathrm{Cs}^{+}$and $144 \mathrm{mM} \mathrm{Na}^{+}$(Fig. 5F), the external $\mathrm{Na}^{+}$may have interfered with $\mathrm{Cs}^{+}$permeation from the outside. Rennie and Correia (2000) found an anomalous mole fraction effect when they varied the relative concentrations of $\mathrm{K}^{+}$and $\mathrm{Cs}^{+}$ions: the conductance was greatest when only $\mathrm{K}^{+}$was present, smaller when only $\mathrm{Cs}^{+}$was present, but smallest of all when both $\mathrm{K}^{+}$and $\mathrm{Cs}^{+}$were present at substantial concentrations. $g_{\mathrm{K}, \mathrm{L}}$ differs in this regard from neuronal $\mathrm{M}$ current (carried by KCNQ channels, see Introduction) which does not show anomalous molefraction behavior (Block and Jones 1996).

\section{DISCUSSION}

As described in the Introduction, Kharkovets et al. (2000) had strong reasons to suggest that both $g_{\mathrm{K}, \mathrm{n}}$ and $g_{\mathrm{K}, \mathrm{L}}$ comprise KCNQ4 subunits, possibly in combination with other subunits. This proposal would have been supported had we found similar biophysical properties, but instead we found marked differences. The activation range of $g_{\mathrm{K}, \mathrm{n}}$ was broader, had a more negative midpoint, and was less sensitive to washout than that of $g_{\mathrm{K}, \mathrm{L}}$. The kinetics of activation and deactivation differed in quantity $\left(g_{\mathrm{K}, \mathrm{n}}\right.$ being faster) and quality ( $g_{\mathrm{K}, \mathrm{n}}$ 's sigmoidal deactivation). The pores differed in their permeability to $\mathrm{Cs}^{+}$. Other studies have shown pharmacological differences. $g_{\mathrm{K}, \mathrm{n}}$ is blocked by relatively low doses of the KCNQ4 blocker linopirdine, unlike $g_{\mathrm{K}, \mathrm{L}}$ (Rennie et al. 2001). $g_{\mathrm{K}, \mathrm{L}}$ is sensitive to 4-aminopyridine (Griguer et al. 1993; Rennie and Correia 1994; Rüsch and Eatock 1996a; Brichta et al. 2002), but $g_{\mathrm{K}, \mathrm{n}}$ is not (Mammano et al. 1995; Oliver et al. 2003). These major biophysical and pharmacological differences indicate important differences in channel structure. The channels may not be related at all, or they may share subunits (e.g., KCNQ4) but have different $\alpha$ - and/or $\beta$-subunit partners or more subtle differences reflecting post-translational modifications.

\section{Functional considerations}

Both of these negatively activating conductances are acquired relatively late in hair cell differentiation, during the first two to three weeks of postnatal life (Rüsch et al. 1998; Marcotti and Kros 1999; Eatock and Hurley 2003; Marcotti et al. 2003). While we can calculate certain aspects of their impact on the 
receptor potential, their roles are not firmly established. Speculation has centered on different aspects of function for the outer hair cells and type I cells.

By reducing the input resistance, $g_{\mathrm{K}, \mathrm{n}}$ and $g_{\mathrm{K}, \mathrm{L}}$ attenuate the steady-state receptor potential and reduce the membrane time constant, $\tau_{\mathrm{m}}$. The latter effect moves the corner frequency for low-pass filtering by the membrane capacitance to higher frequencies. Marcotti and Kros (1999) found that the postnatal acquisition of $g_{\mathrm{K}, \mathrm{n}}$ by outer hair cells in the mouse apical turn reduces $\tau_{\mathrm{m}}$ sevenfold, from $11.8 \pm 1.36 \mathrm{~ms}(n=11)$ to $1.6 \pm 0.10 \mathrm{~ms} \quad(n=15)$, raising the low-pass corner frequency for charging the membrane capacitance from about 10 to $100 \mathrm{~Hz}$. The effect of $g_{\mathrm{K}, \mathrm{L}}$ on type I hair cells is even more extreme because its extraordinarily large size produces unusually low input resistances. In the rat utricle, type I hair cells have a median input resistance of $37 \mathrm{M} \Omega$ $(n=55)$ vs. $1.2 \mathrm{G} \Omega$ for type II hair cells $(n=39)$ (ruptured-patch recordings, M. Saeki and R.A. Eatock, unpublished results). Assuming membrane capacitances of $4 \mathrm{pF}$ (our mean value), the median membrane time constants of rat utricular type I and type II hair cells are about $160 \mu$ s and $5 \mathrm{~ms}$, respectively, corresponding to low-pass corner frequencies of about 1000 and $30 \mathrm{~Hz}$. Similarly, the membranes of type I and type II hair cells from gerbil semicircular canals have low-pass corner frequencies of 400$5000 \mathrm{~Hz}$ and $40 \mathrm{~Hz}$, respectively (Rennie et al. 1996). The significance of the higher bandwidth of type I cells is not known. Head movement energy falls off at high frequencies, with the highest known effective stimuli in the range of $20-30 \mathrm{~Hz}$ (Angelaki 1998; Hullar and Minor 1999). Moreover, type I hair cells acquire bandwidth at the cost of receptor potential gain, so that it is not clear whether type I or type II cells generate larger receptor potentials at high stimulus frequencies.

Several authors have suggested that $g_{\mathrm{K}, \mathrm{n}}$ is important in $\mathrm{K}^{+}$circulation within the cochlea (see Introduction). Its appearance at hearing onset in the hair cell's basal membrane might reflect the emerging need for cochlear hair cells to rapidly clear $\mathrm{K}^{+}$flowing in through apical transduction channels (Kennedy et al. 2003; Marcotti et al. 2003). In type I hair cells, $g_{\mathrm{K}, \mathrm{L}}$ appears at the same time as calyx afferent endings, which tightly envelop most of the basolateral membrane-an arrangement not conducive to $\mathrm{K}^{+}$clearance from the extracellular space. Indeed, it has been argued that accumulation of $\mathrm{K}^{+}$in the space between the hair cell and calyx (the cleft) may constitute a form of nonquantal synaptic transmission from the type I cell to the calyx ending (Goldberg 1996). Increased cleft $\mathrm{K}^{+}$will depolarize the calyx by depolarizing $E_{k}$, provided that the calyx membrane facing the hair cell (the calyx inner face) has a $\mathrm{K}^{+}$conductance.
Ultrastructural localization of KCNQ4 immunoreactivity suggests that the calyx inner face is well endowed with KCNQ4 channels (Kharkovets et al. 2000; Lysakowski and Price 2003). An alternative kind of nonquantal transmission at this synapse may be ephaptic transmission via direct current flow into the calyx ending (Trussell 2000). As current leaves the hair cell, it flows along the synaptic cleft or into the calyx ending. At most synapses, most of the current exiting the presynaptic terminal flows through the low-resistance extracellular space. Ephaptic transmission may be enhanced at the type I hair cell-calyx interface by the relatively high resistance of the extracellular space-a thin shell-and the relatively low resistance of the postsynaptic membrane (as suggested by immunostaining evidence for numerous KCNQ4 channels). While such putative nonquantal pathways might operate at these synapses, chemical transmission certainly also occurs, given that type I hair cells have abundant synaptic ribbons and vesicles (Lysakowski and Goldberg 1997).

The vulnerability of $g_{\mathrm{K}, \mathrm{L}}$ to washout during recording and to agents such as nitric oxide (Chen and Eatock 2000), cGMP (Behrend et al. 1997; Rennie 2002) and protein kinase inhibitors (Eatock et al. 2002) suggests that $g_{\mathrm{K}, \mathrm{L}}$ might be modulated in vivo. Suppression of $g_{\mathrm{K}, \mathrm{L}}$ would enhance input resistance and the gain of conventional (quantal) transmission from the type I hair cell to the calyx ending (see Discussion in Chen and Eatock 2000).

\section{Comparison with KCNQ conductances}

When we compare $g_{\mathrm{K}, \mathrm{n}}$ and $g_{\mathrm{K}, \mathrm{L}}$ with heterologously expressed KCNQ conductances or with native $\mathrm{M}$ or M-like conductances, we find, for each of the hair cell conductances, some differences and some similarities. Heterologously expressed KCNQ channels and $\mathrm{M}$ channels have more positive activation ranges than either $g_{\mathrm{K}, \mathrm{n}}$ or $g_{\mathrm{K}, \mathrm{L}}$, with $V_{1 / 2}$ values ranging from -5 to $-50 \mathrm{mV}$ (Biervert et al. 1998; Schroeder et al. 2000; Selyanko et al. 2000; Pan et al., 2001). $g_{\mathrm{K}, \mathrm{n}}$ behaves like other KCNQ channels (Robbins et al. 1992) in being insensitive to 4-aminopyridine (Mammano et al. 1995; Marcotti et al. 2003), which blocks $g_{\mathrm{K}, \mathrm{L}}$ (Rennie and Correia 1994; Rüsch and Eatock 1996a; Brichta et al. 2002). The block of $g_{\mathrm{K}, \mathrm{L}}$ by 4 -aminopyridine has a substantial voltage- (or state-) dependent component that is relieved at depolarized potentials (Brichta et al. 2002). $g_{\mathrm{K}, \mathrm{L}}$ has a $P_{\mathrm{Cs}} / P_{k}$ value comparable to that of $\mathrm{M}$ channels (Cloues and Marrion 1996; Block and Jones 1996) and heterologously expressed KCNQ4 channels (Kubisch et al. 1999), but unlike M channels (Block and Jones 1996) it displays anomalous mole-fraction behavior (Rennie and Correia 2000$)$. 
None of these comparisons can rule in or out a particular molecular composition for $g_{\mathrm{K}, \mathrm{n}}$ or $g_{\mathrm{K}, \mathrm{L}}$. $\mathrm{K}^{+}$ conductances may share $\alpha$ subunits but have distinct properties; a relevant example is provided by $g_{\mathrm{K}, \mathrm{n}}$ and heterologously expressed KCNQ4 channels $\left(g_{\mathrm{KCNQ} 4}\right)$. Despite strong evidence that $g_{\mathrm{K}, \mathrm{n}}$ is carried by KCNQ4-containing subunits, $g_{\mathrm{K}, \mathrm{n}}$ has a more negative activation range, faster kinetics, and much greater sensitivity to linopirdine than does $g_{\mathrm{KCNQ}}$. Heterologous expression experiments have shown that the same KCNQ genes can give rise to distinct ion channels through splice variation (Pan et al. 2001), association with other subunits (e.g., Wang et al. 2000), or phosphorylation (Gamper et al. 2003). Channels formed by coexpressing KCNQ4 with KCNQ3, which is also expressed in the cochlea and vestibular organs (Kubisch et al. 1999), have an activation range and linopirdine sensitivity somewhat closer to those of $g_{\mathrm{K}, \mathrm{n}}$ channels (Kubisch et al. 1999). Yet the properties are still quite far apart: The activation $V_{1 / 2}$ was more positive by $70 \mathrm{mV}$ and the half-blocking linopirdine dose was more than 100-fold larger for KCNQ3/4 channels than for $g_{\mathrm{K}, \mathrm{n}}$ channels. These discrepancies illustrate the challenges of understanding the molecular basis of ion channel properties in vivo.

The evidence that $g_{\mathrm{K}, \mathrm{n}}$ is a KCNQ4 conductance is not ironclad but leaves little room for doubt. As reviewed in the Introduction, KCNQ4 is expressed at both the message and protein levels by the cells that have $g_{\mathrm{K}, \mathrm{n}}$, and that expression coincides with the developmental appearance of $g_{\mathrm{K}, \mathrm{n}}$. Importantly, $g_{\mathrm{K}, \mathrm{n}}$ is the only cochlear hair cell conductance that is blocked by KCNQ blockers, i.e., there are no other candidates for the KCNQ4 conductance. The published evidence that $g_{\mathrm{K}, \mathrm{L}}$ includes KCNQ4 subunits is somewhat less firm. On the positive side, KCNQ4 mRNA expression in vestibular epithelia and KCNQ4like immunoreactivity in type I hair cells coincide with the developmental acquisition of $g_{\mathrm{K}, \mathrm{L}}$ (Kharkovets et al. 2000). There is also a preliminary report that transfection of mouse utricular hair cells with a dominant negative form of KCNQ4 eliminates $g_{\mathrm{K}, \mathrm{L}}$ expression (Holt et al. 2004). There are, however, several reasons to question the identification of $g_{\mathrm{K}, \mathrm{L}}$ as a KCNQ4 conductance. First, the data from the present study argue for significant molecular differences relative to $g_{\mathrm{K}, \mathrm{n}}$, which is almost certainly a KCNQ4 conductance. Second, in vestibular epithelia there are other potential ion channel candidates for the KCNQ4 mRNA: Type II vestibular hair cells have a conductance that is not $g_{\mathrm{K}, \mathrm{L}}$ and that is sensitive to KCNQ blockers (Rennie et al. 2001; K.M. Hurley and R.A. Eatock, unpublished results). Finally, preliminary reports suggest that much of the KCNQ4 immunostaining that has been attributed to the type I hair cell is actually in the calyx ending (Lysakowski and Price 2003) and that $g_{\mathrm{K}, \mathrm{L}}$ is sensitive to blockers of the ether-a-go-go family of $\mathrm{K}^{+}$channels (Hurley and Eatock 2002). The contradictory observations on $g_{\mathrm{K}, \mathrm{L}}$ even raise the possibility that it comprises more than one channel type, i.e., that type I cells have multiple negatively activating $\mathrm{K}^{+}$channel types, with different ones dominating in different developmental stages, zones of the epithelia, or experimental conditions.

\section{ACKNOWLEDGMENTS}

This research was supported by NIH grant DC02290 and by funds from the Karim Al-Fayed Neurobiology of Hearing Laboratory. We thank Dr. Julian Wooltorton and Jasmine Garcia for comments on the manuscript and Jasmine Garcia and Donna Himes for technical assistance.

\section{REFERENCES}

ANGELAKI DE. Three-dimensional organization of otolith-ocular reflexes in rhesus monkeys. III. Responses to translation. J. Neurophysiol. 80:680-695, 1998.

Angelo K, Jespersen T, Grunnet M, Nielsen MS, Klaerke DA, Olesen SP. KCNE5 induces time- and voltage-dependent modulation of the KCNQ1 current. Biophys. J. 83:1997-2006, 2002.

ARt JJ, FETTIPLACE R. Variation of membrane properties in hair cells isolated from the turtle cochlea. J. Physiol. 385:207-242, 1987.

Ashmore JF. Forward and reverse transduction in the mammalian cochlea. Neurosci. Res. Suppl 12:S39-S50, 1990.

BARRY PH. JPCalc, a software package for calculating liquid junction potential corrections in patch-clamp, intracellular, epithelial and bilayer measurements and for correcting junction potential measurements. J. Neurosc. Meth. 51:107-116, 1994.

Behrend O, Schwark G, Kunihiro T, Strupp M. Cyclic, GMP inhibits and shifts the activation curve of the delayed-rectifier $\left(\mathrm{I}_{\mathrm{K} 1}\right)$ of type I mammalian vestibular hair cells. NeuroReport 8:2687-2690, 1997.

Beisel KW, Nelson NC, Delimont DC, Fritzsch B. Longitudinal gradients of KCNQ4 expression in spiral ganglion and cochlear hair cells correlate with progressive hearing loss in DFNA2. Brain Res. Mol. Brain Res. 82:137-149, 2000.

Beurg M, Bouleau Y, Dulon D. The voltage-sensitive motor protein and the $\mathrm{Ca}^{2+}$-sensitive cytoskeleton in developing rat cochlear outer hair cells. Eur. J. Neurosci. 14:1947-1952, 2001.

Biervert G, Schroeder BG, Kubisch G, Berkovic SF, Propping P, Jentsch TJ, Steinlein OK. A potassium channel mutation in neonatal human epilepsy. Science 279:403-406, 1998.

BLOCK BM, JonES SW. Ion permeation and block of M-type and delayed rectifier potassium channels. Whole-cell recordings from bullfrog sympathetic neurons. J. Gen. Physiol. 107:473-488, 1996.

Brichta AM, Aubert A, Eatock RA, Goldberg JM. Regional analysis of whole cell currents from hair cells of the turtle posterior crista. J. Neurophysiol. 88:3259-3278, 2002.

CHen JWY, EATock RA. Major potassium conductance in type I hair cells from rat semicircular canals: Characterization and modulation by nitric oxide. J. Neurophysiol. 84:139-151, 2000.

Cloues R, Marrion NV. Conduction properties of the M-channel in rat sympathetic neurons. Biophys. J. 70:806-812, 1996.

Correia MJ, LANG DG. An electrophysiological comparison of solitary type I and type II vestibular hair cells. Neurosci. Lett. 116:106-111, 1990. 
DiFrancesco D, Ferroni A, Mazzanti M, Tromba C. Properties of the hyperpolarizing-activated current (I-f) in cells isolated from the rabbit sino-atrial node. J. Physiol. 377:61-88, 1986.

Eatock RA, Hurley KM. Functional development of hair cells. In: Romand R, Varela-Nieb I (eds) Development of the Auditory and Vestibular Systems 3: Molecular Development of the Inner Ear. Academic Press, San Diego, pp 389-448, 2003.

Eatock RA, Chen WY, SAeKi M. Potassium currents in mammalian vestibular hair cells. Sensory Systems 8:21-28, 1994.

Eatock RA, Hurley KM, Vollrath MA. Mechanoelectrical and voltage-gated ion channels in mammalian vestibular hair cells. Audiol. Neurootol. 7:31-35, 2002.

FETTIPLACE R. The role of calcium in hair cell transduction. In: Corey DP, Roper SD (eds) Sensory Transduction. The Rockefeller University Press, New York, pp 344-356, 1992.

Fuchs PA, Nagai T, Evans MG. Electrical tuning in hair cells isolated from the chick cochlea. J. Neurosci. 8:2460-2467, 1988.

Gamper N, Stockand JD, Shapiro MS. Subunit-specific modulation of KCNQ potassium channels by Src tyrosine kinase. J. Neurosci. 23:84-95, 2003.

GOLDBERG JM. A theoretical analysis of intercellular communication between the vestibular type I hair cell and its calyx ending. J. Neurophysiol. 76:1942-1957, 1996.

Griguer G, Sans A, Lehoullleur J. Non-typical $\mathrm{K}^{+}$-current in cesiumloaded guinea pig type I vestibular hair cell. Pflügers Arch. 422:407-409, 1993.

Hamill OP, Marty A, Neher E, Sakmann B, Sigworth FJ. Improved patch-clamp techniques for high-resolution current recording from cells and cell-free membrane patches. Pflügers Arch. 391:85-100, 1981.

Holt JR, Eatock RA. The inwardly rectifying currents of saccular hair cells from the leopard frog. J. Neurophysiol. 73:1484-1502, 1995.

Holt JR, Aвraham D, GÉLÉoc GS. Adenoviral-mediated dominantnegative suppression of a low-voltage-activated potassium conductance in type I vestibular hair cells. Abstr. Annu. Meet. Assoc. Res. Otolaryngol. 27:153.

HoRn R, MARTY A. Muscarinic activation of ionic currents measured by a new whole-cell recording method. J. Gen. Physiol. 92:145159, 1988.

Housley GD, Ashmore JF. Ionic currents of outer hair cells isolated from the guinea-pig cochlea. J. Physiol. 448:73-98, 1992.

HudsPeth AJ, CoREy DP. Sensitivity, polarity, and conductance change in the response of vertebrate hair cells to controlled mechanical stimuli. Proc. Natl. Acad. Sci. USA 74:2407-2411, 1977.

HudSPETH AJ, Lewis RS. Kinetic analysis of voltage- and ion-dependent conductances in saccular hair cells of the bull-frog, Rana catesbeiana. J Physiol. 400:237-274, 1988.

Hullar TE, Minor LB. High-frequency dynamics of regularly discharging canal afferents provide a linear signal for angular vestibuloocular reflexes. J. Neurophysiol. 82:2000-2005, 1999.

HuRLey KM, ЕATOcK RA. Heterogeneous expression of $\mathrm{K}^{+}$conductances in vestibular type I hair cells. Abstr. Annu. Meet Assoc. Res. Otolaryngol. 25:61, 2002.

Kennedy HJ, Evans MG, Crawford AC, Fettiplace R.. Fast adaptation of mechanoelectrical transducer channels in mammalian cochlear hair cells. Nat. Neurosci. 6:832-836, 2003.

Kharkovets T, Hardelin J-P, Safieddine M, Fettiplace R., El-Amraoui A, Petit C, Jentsch TJ. KCNQ4, a $\mathrm{K}^{+}$channel mutated in a form of dominant deafness, is expressed in the inner ear and the central auditory pathway. Proc. Natl. Acad. Sci. USA 97:43334338, 2000.

Kikuchi T, Kimura RS, Paul DL, Takasaka T, Adams JC. Gap junction systems in the mammalian cochlea. Brain Res. Brain Res. Rev. 32:163-166, 2000.
Kubisch C, Schroeder BC, Friedrich, Lüjohann B, El-Amraoui A, Marlin S, Petit C, Jentsch TJ. KCNQ4, a novel potassium channel expressed in sensory outer hair cells, is mutated in dominant deafness. Cell 96:437-446, 1999.

Lysakowski A, Goldberg JM. Regional variations in the cellular and synaptic architecture of the chinchilla cristae. J. Comp. Neurol. 389:419-443, 1997.

Lysakowski A, Price SD. Ultrastructural localization of potassium channels in the inner ear. FASEB 17:A1228.

Mammano F, Ashmore JF. Differential expression of outer hair cell potassium currents in the isolated cochlea of the guinea-pig. J. Physiol. 496:639-646, 1996.

Mammano F, Kros CJ, Ashmore JF. Patch clamped responses from outer hair cells in the intact adult organ of Corti. Pflügers Arch. 430:745-750, 1995.

Marcotti W, Kros CJ. Developmental expression of the potassium current $\mathrm{I}_{\mathrm{K}, \mathrm{n}}$ contributes to maturation of mouse outer hair cells. J. Physiol. 520:653-660, 1999.

Marcotti W, GélÉoc GS, Lennan GW, Kros CJ. Transient expression of an inwardly rectifying potassium conductance in developing inner and outer hair cells along the mouse cochlea. Pflügers Arch. 439:113-122, 1999.

Marcotti W, Johnson SL, Holley MC, Kros GJ. Developmental changes in the expression of potassium currents of embryonic, neonatal and mature mouse inner hair cells. J. Physiol. 548:383400, 2003.

Masetto S, Perin P, Malusa A, Zucca G, Valli P. Membrane properties of chick semicircular canal hair cells in situ during embryonic development. J. Neurophysiol. 83:2740-2756, 2000.

MulLER M. Developmental changes of frequency representation in the rat cochlea. Hear. Res. 56:1-7, 1991.

Oliver D, FakLer B. Expression density and functional characteristics of the outer hair cell motor protein are regulated during postnatal development in rat. J. Physiol. 519:791-800, 1999.

Oliver D, Knipper M, Derst G, Fakler B. Resting potential and submembrane calcium concentration of inner hair cells in the isolated mouse cochlea are set by KCNQ-type potassium channels. J. Neurosci. 23:2141-2149, 2003.

Pan Z, Selyanko AA, Hadley JK, Brown DA, Dixon JE, McKinnon D. Alternative splicing of KCNQ2 potassium channel transcripts contributes to the functional diversity of M-currents. J. Physiol. 531:347-358, 2001

ReNnIE KJ. Modulation of the resting potassium current in type I vestibular hair cells by cGMP. In: BerLin GI, Hood LJ, Ricci AJ. (eds) Hair Cell Micromechanics and Otoacoustic Emissions. Singular Press, San Diego, pp 79-89, 2002.

RenNie KJ, Correia MJ. Potassium currents in mammalian and avian isolated type I semicircular canal hair cells. J. Neurophysiol. 71:317-329, 1994.

Rennie KJ, Correia MJ. Effects of cationic substitutions on delayed rectifier current in type I vestibular hair cells. J. Membr. Biol. 173:139-148, 2000.

Rennie KJ, Ricci AJ, Correia MJ. Electrical filtering in gerbil isolated type I semicircular canal hair cells. J. Neurophysiol. 75:21172123, 1996.

Rennie KJ, Weng T, Correia MJ. Effects of KCNQ channel blockers on $\mathrm{K}(+)$ currents in vestibular hair cells. Am. J. Physiol. Cell Physiol. 280:C473-C480, 2001.

Ricci AJ, Rennie KJ, Correia MJ. The delayed rectifier, $\mathrm{I}_{\mathrm{KI}}$, is the major conductance in type I vestibular hair cells across vestibular end organs. Pflügers Arch. 432:34-42, 1996.

Robbins J, Trouslard J, Marsh SJ, Brown DA. Kinetic and pharmacological properties of the M-current in rodent neuroblastoma $\times$ glioma hybrid cells. J. Physiol. 451:159-185, 1992.

RüBSAMEN R, LIPPE WR. The development of cochlear function. In: Rubel EW, Popper AN, Fay RR (eds) Development of the Auditory System. Springer-Verlag, New York, pp 193-270, 1998. 
Rüsch A, Eatock RA. A delayed rectifier conductance in type I hair cells of the mouse utricle. J. Neurophysiol. 76:995-1004, 1996a.

Rüsch A, EATOCK RA. Voltage responses of mouse utricular hair cells to injected currents. Ann. NY Acad. Sci. 781:71-84, 1996b.

Rüsch A, Lysakowski A, Eatock RA. Postnatal development of type I and type II hair cells in the mouse utricle: Acquisition of voltage-gated conductances and differentiated morphology. J. Neurosci. 18:7487-7501, 1998.

Sanguinetti MC, Curran Me, Zou A, Shen J, Spector PS, Atkinson DL, Keating MT. Coassembly of K(V)LQT1 and minK (IsK) proteins to form cardiac I(Ks) potassium channel. Nature. 384:80-83, 1996.

SANTOS-SACchi J. Reversible inhibition of voltage-dependent outer hair cell motility and capacitance. J. Neurosci. 11:3096-3110, 1991.

Santos-Sacchi J. Cell coupling in Corti's organ. Brain Res. Rev. 32:167-171, 2000.

SANTOS-SACChI J, HuAng GJ, Wu M. Mapping the distribution of outer hair cell voltage-dependent conductances by electrical amputation. Biophys. J. 73:1424-1429, 1997.

Schroeder BC, Hechenberger M, Weinreich F, Kubisch C, Jentsch TJ. KCNQ5, a novel potassium channel broadly expressed in brain, mediates M-type currents. J. Biol. Chem. 275:24089-24095, 2000.

Selyanko AA, Hadley JK, Wood IC, Abogadie FC, Jentsch TJ, Brown DA. Inhibition of KCNQ1-4 potassium channels expressed in mammalian cells via M1 muscarinic acetylcholine receptors. J. Physiol. 522(Pt 3):349-355, 2000.

Shah MM, Mistry M, Marsh SJ, Brown DA, Delmas P. Molecular correlates of the M-current in cultured rat hippocampal neurons. J. Physiol. 544:29-37, 2002.

Smotherman MS, Narins PM. The electrical properties of auditory hair cells in the frog amphibian papilla. J. Neurosci. 19:52755292, 1999.

Sugihara I, Furukawa T. Morphological and functional aspects of two different types of hair cells in the goldfish sacculus. J. Neurophysiol. 62(6):1330-1343, 1989.

Sugihara I, Furukawa T. Inwardly rectifying currents in hair cells and supporting cells in the goldfish sacculus. J Physiol. 495:665$679,1996$.

Trussell L. Mutant ion channel in cochlear hair cells causes deafness. Proc. Natl. Acad. Sci. USA 97:3786-3788, 2000.

Uziel A, Romand R, Marot M. Development of cochlear potentials in rats. Audiology. 20:89-100, 1981.

Wang HS, Pan Z, Shi W, Brown BS, Wymore RS, Cohen IS, Dixon JE, MCKINNON D. KCNQ2 and KCNQ3 potassium channel subunits: Molecular correlates of the M-channel. Science 282:1890-1893, 1998.

Wang HS, Brown BS, McKinnon D, Cohen IS. Molecular basis for differential sensitivity of $\mathrm{KCNQ}$ and $\mathrm{I}(\mathrm{Ks})$ channels to the cognitive enhancer. Mol. Pharmacol. 57:1218-1223, 2000.

WANGEMANN P. $\mathrm{K}(+)$ cycling and its regulation in the cochlea and the vestibular labyrinth. Audiol Neurootol. 7:199-205, 2002. 